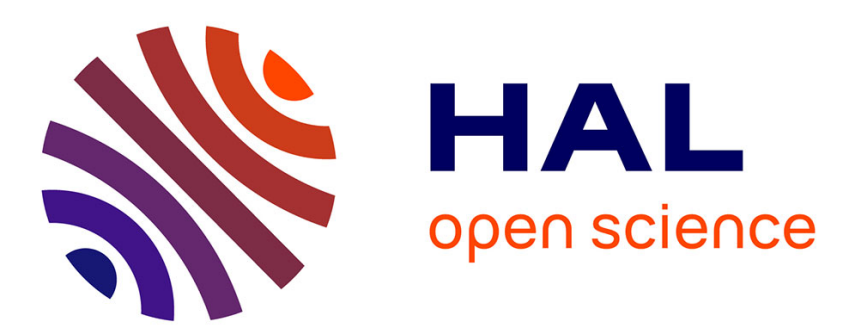

\title{
Microbial responses to mustard gas dumped in the Baltic Sea
}

Nadezda Medvedeva, Yulia Polyak, Harri Kankaanpää, Tatyana Zaytseva

\section{To cite this version:}

Nadezda Medvedeva, Yulia Polyak, Harri Kankaanpää, Tatyana Zaytseva. Microbial responses to mustard gas dumped in the Baltic Sea. Marine Environmental Research, 2009, 68 (2), pp.71. 10.1016/j.marenvres.2009.04.007 . hal-00563076

\section{HAL Id: hal-00563076 https://hal.science/hal-00563076}

Submitted on 4 Feb 2011

HAL is a multi-disciplinary open access archive for the deposit and dissemination of scientific research documents, whether they are published or not. The documents may come from teaching and research institutions in France or abroad, or from public or private research centers.
L'archive ouverte pluridisciplinaire HAL, est destinée au dépôt et à la diffusion de documents scientifiques de niveau recherche, publiés ou non, émanant des établissements d'enseignement et de recherche français ou étrangers, des laboratoires publics ou privés. 


\section{Accepted Manuscript}

Microbial responses to mustard gas dumped in the Baltic Sea

Nadezda Medvedeva, Yulia Polyak, Harri Kankaanpä ä, Tatyana Zaytseva

PII:

S0141-1136(09)00039-7

DOI:

10.1016/j.marenvres.2009.04.007

Reference:

MERE 3332

To appear in:

Marine Environmental Research

Received Date:

12 November 2008

Revised Date:

8 April 2009

Accepted Date:

10 April 2009

Please cite this article as: Medvedeva, N., Polyak, Y., Kankaanpä ä, H., Zaytseva, T., Microbial responses to mustard gas dumped in the Baltic Sea, Marine Environmental Research (2009), doi: 10.1016/j.marenvres.2009.04.007

This is a PDF file of an unedited manuscript that has been accepted for publication. As a service to our customers we are providing this early version of the manuscript. The manuscript will undergo copyediting, typesetting, and review of the resulting proof before it is published in its final form. Please note that during the production process errors may be discovered which could affect the content, and all legal disclaimers that apply to the journal pertain. 


\section{Microbial responses to mustard gas dumped in the Baltic Sea}

Nadezda Medvedeva $^{1}$, Yulia Polyak ${ }^{1 *}$, Harri Kankaanpää ${ }^{2}$, Tatyana Zaytseva ${ }^{1}$

${ }^{1}$ Scientific Research Centre of Ecological Safety RAS, 18, Korpusnaya St., 197110, St.Petersburg, Russia

${ }^{2}$ Finnish Institute of Marine Research, Erik Palménin aukio 1, FIN-00560 Helsinki, Finland

${ }^{*}$ Corresponding author. Tel. +7 81223078 40, fax. +7 8122354361. E-mail address: yuliapolyak@mail.ru, oorlova@yandex.ru (Yulia Polyak). 
Microbiological studies were carried out on chemical weapon dump sites in the Baltic Sea. The effect of mustard gas hydrolysis products (MGHPs) on marine microbiota and the ability of microorganisms to degrade MGHPs were studied. Many stations at the dump sites demonstrated reduced microbial diversity, and increased growth of species able to use mustard gas hydrolysis products as sole source of carbon. Significant amounts of MGHP-degrading bacteria were revealed in the nearbottom water. The MGHP-degrading microorganisms identified as Achromobacter sp., Pseudomonas sp., and Arthrobacter sp. were isolated. These microorganisms were capable of utilizing the major product of hydrolysis, thiodiglycol, as the sole source of carbon and energy. The bacteria were capable of metabolizing MGHPs at a low temperature. The metabolic pathway for thiodiglycol degradation was proposed. The results suggest the potential for MGHPs biodegradation by naturally occurring populations of near-bottom-water and sediment microorganisms.

Keywords: Bacteria, Baltic Sea, Chemical weapon, Sea dumping, Mustard gas, Degradation, Self purification.

Abbreviations: CWA, chemical warfare agents; MGHPs, mustard gas hydrolysis products; TDG, thiodiglycol; OCS, organochlorine substances; TDGA, thiodiglycolic acid; TGA, thioglycolic acid; HETA, [(2-hydroxyethyl)thio]acetic acid. 


\section{Introduction}

Tens of thousands of tons of captured German chemical munitions have been dumped in the Baltic Sea since World War II. It is estimated that the chemical munitions contained about 13,000 tons of chemical warfare agents (HELCOM, 1994). The dumping of munitions at sea by the allied countries was done in the southern and western Baltic, mainly in the Gotland Basin, the Bornholm Basin, the Little Belt and the Skagerrak Strait (Fig. 1).

In most cases the warfare agents were thrown overboard, either loose (bombs, shells) or in containers, but some ships were also sunk (HELCOM, 1996). During transportation to the dumping areas some munitions were thrown overboard while the ships were en route. Warfare agents are, therefore, assumed to be spread over a considerable area along the transport routes (Schulz-Ohlberg et al., 2001). Chemical munitions have been spread even further by fishing vessels when trawling. Table 1 gives an overview of the quantities of chemical munitions and warfare agents dumped in the Baltic Sea and Skagerrak (Chemical munitions, 1993).

The largest number of chemical agents was dumped in the Bornholm Basin, east of the island of Bornholm. Fishermen still recover bombs, shells and lumps of mustard gas in their nets in this area (HELCOM, 1993).

Over the period 2000-2005 up to $1,010 \mathrm{~kg}$ of chemical munitions a year were netted by fishermen east of Bornholm (HELCOM, 2005). The netted munitions were completely corroded and resembled clay-like lumps of mustard gas. The highest number of incidents during the last 20 years was in 1991 with 103 catches amounting to $5,378 \mathrm{~kg}$ of chemical warfare agents. The most recent report of recovery of bomb containing mustard gas and tear gas Clark I came from Sweden in 2007 (Åstot et al., 2007).

Most accidents with warfare agents so far have involved mustard gas. Because of the admixture of thickeners, viscous mustard gas is the only warfare agent occurring in large lumps that are mechanically relatively stable and can exist unchanged for decades on the sea bed. All injuries to fishermen have occurred when liquid or solid mustard gas has escaped from rusted munitions and come into contact with the skin. The mustard gas causes severe blistering of the skin and irritates the eyes and throat (Glasby, 1997).

Mustard gas is extremely toxic for all species (Opresko et al., 1998). Because of its high lipid solubility mustard gas rapidly penetrates cells. It is able to alkylate DNA, RNA, and proteins affecting a variety of cell functions (Papirmeister et al., 1991). The products of mustard gas hydrolysis have a wide spectrum of toxic activity on soil microbiota (Medvedeva et al., 2008). They are known to change significantly the number and the specific composition of soil microorganisms (Medvedeva et al., 2006). Contamination of soil with mustard gas causes significant ecological shifts, such as a decrease in the similarity index and the diversity index of microbiota, and a decrease in the dominance index. Microbial succession is accompanied by a decrease 
in the fermentative activity of soils (Medvedeva et al., 2000).

To assess the risk relating to dumped chemical weapons, it is necessary to evaluate the ability of the ecosystem itself (and microbiota as its component) for selfpurification of contaminated water and sediments. The ability of microorganisms to carry out mineralization of organic substances, in particular, toxicants of various chemical natures is well known and widely used in practice and scientific research (Oldenhuis et al., 1992). Because of its high degree of toxicity, mustard gas is generally resistant to microbial attack. However, several studies have demonstrated that mustard gas is subject to biodegradation by a limited number of naturally occurring species.

Biodegradation of mustard gas by basidiomycetes, Coriolus versicolor and Tyromyces palustris, has been reported (Wariishi et al., 2002). Bacteria Micrococcus sp. 6-2 and Pseudomonas sp. 8-2 were able to metabolize the products of mustard gas hydrolysis, particularly those that were chlorinated (Medvedeva et al., 2000). Bacterium Rhodococcus rhodochrous IQTS8 had the ability to utilize a chemical analog of mustard gas 2-chloroethyl-ethylsulfide as the only carbon and energy source for growth (Kilbane \& Jackowski, 1996).

More studies are concerned with thiodiglycol (TDG), the major product of mustard gas hydrolysis (Munro et al., 1999). Thiodiglycol is a fairly stable substance with weak toxicity. Nevertheless, it is one of the war gas precursors that must be destroyed, according to the Chemical Weapons Convention. In this connection, biodegradation of mustard gas is closely related to the utilization of TDG by microorganisms. Soil bacteria Pseudomonas pikettii SH18 and Alcaligenes xylosoxydans ssp. xylosoxydans SH42 (Harvey et al., 1993), Micrococcus sp. 6-2 and Pseudomonas sp. 8-2 (Medvedeva et al., 2000), Pseudomonas sp. Y-13 (Medvedeva et al., 2006), Alcaligenes xylosoxydans PGH 10 (Garcia-Ruiz et al., 2002), Alcaligenes xylosoxydans subsp. denitrificans TD 1 (Ermakova et al., 2002), Alcaligenes xylosoxydans ssp. xylosoxydans SH91 (Lee et al., 1996) are capable of using TDG as the sole source of carbon. While degradation of thiodiglycol has been characterized in terrestrial isolates, little is known about marine-degrading microorganisms.

The goal of our study was to investigate the effect of warfare agents on the Baltic Sea microbiota. We report in this paper on the isolation, characterization and metabolic activities of the bacteria able to use mustard gas hydrolysis products as the sole source of carbon and energy.

\section{Materials and methods}

\subsection{Sampling}


Seawater samples were collected from Baltic Sea chemical weapon dump sites in 1994-2007. The water samples were taken from the Bornholm dump site, Gotland Basin, and Skagerrak Strait. Water samples $(100 \mathrm{ml})$ were collected from the whole water column using sterile bathometers. Near-bottom water $(100 \mathrm{ml})$ was taken from Niemistö corers and put into sterile plastic flasks.

\subsection{Enumeration of microorganisms}

The number of heterotrophic microorganisms and content of heterotrophic microorganisms able to degrade mustard gas hydrolysis products (MGHPs) were analyzed immediately after sampling. The total number of microorganisms was determined after conservation with formalin using the standard technique (Tsyban, 1980). The number of heterotrophic microorganisms was estimated using inoculation on nutrient agar (1:10) (Kuznetsov \& Dubinina, 1989). The incubation time was 3-5 days. The content of heterotrophic microorganisms able to degrade MGHPs was determined by inoculation on selective agar with water samples. The incubation time was 7 - 10 days. The selective agar had the following composition: $\left(\mathrm{NH}_{4}\right)_{2} \mathrm{SO}_{4} 4.0 \mathrm{~g} / \mathrm{l}$, $\mathrm{KH}_{2} \mathrm{PO}_{4} 1.5 \mathrm{~g} / \mathrm{l}, \mathrm{K}_{2} \mathrm{HPO}_{4} 1.5 \mathrm{~g} / \mathrm{l}, \mathrm{MgSO}_{4} 0.2 \mathrm{~g} / \mathrm{l}, \mathrm{NaCl} 5.0 \mathrm{~g} / \mathrm{l}$ and agar $20.0 \mathrm{~g} / \mathrm{l}$. Mustard gas hydrolysis products $(16 \mathrm{mg} / \mathrm{l}$ of organochlorine substances (OCS) and $0.35 \mathrm{mg} / \mathrm{l}$ of thiodiglycol) were added to this selective medium as the sole source of carbon.

\subsection{Isolation of microorganisms, media, and culture conditions}

Samples from the flasks were streaked onto plates containing mineral salts medium $\left(4.0 \mathrm{~g} / \mathrm{l}\left(\mathrm{NH}_{4}\right)_{2} \mathrm{SO}_{4}, 1.5 \mathrm{~g} / 1 \mathrm{KH}_{2} \mathrm{PO}_{4}, 1.5 \mathrm{~g} / 1 \mathrm{~K}_{2} \mathrm{HPO}_{4}, 0.2 \mathrm{~g} / 1 \mathrm{MgSO}_{4}, 5.0 \mathrm{~g} / \mathrm{l}\right.$ $\mathrm{NaCl}$ ) solidified with $1.5 \%$ agar. Mustard gas hydrolysis products, including $25 \mathrm{mg} / \mathrm{l}$ of organochlorine substances (OCS), were used as the sole source of carbon. The plates were incubated at $20^{\circ} \mathrm{C}$ for up to 3 weeks. A rapidly growing, visually distinct colony and a separate, morphologically unique isolate were selected for further analysis and purified by repeated plating.

The selected strains of microorganisms were cultivated by three methods:

(1) By inoculation into a solid medium with the following composition $(\mathrm{g} / \mathrm{l})$ : $\left(\mathrm{NH}_{4}\right)_{2} \mathrm{SO}_{4} 4.0, \mathrm{KH}_{2} \mathrm{PO}_{4} 1.5, \mathrm{~K}_{2} \mathrm{HPO}_{4} 1.5, \mathrm{MgSO}_{4} 0.2, \mathrm{NaCl} 5.0$, thiodiglycol 2.0, $\mathrm{CaCO}_{3}$ 2.5, agar 20.0. The control parameters included the occurrence of growth and dissolution of $\mathrm{CaCO}_{3}$, which gives evidence of the formation of acidic products of thiodiglycol degradation;

(2) Cultivation under static conditions: in 20-ml test tubes filled with $17 \mathrm{ml}$ of seawater containing MGHPs (32 $\mathrm{mg}$ OCS/ 1 and $0.96 \mathrm{~g} / \mathrm{l} \mathrm{TDG}$ ), $\mathrm{pH} 7.8 \pm 0.2$. The MGHPs solutions, pre-sterilized separately by filtering through membrane filters with a pore diameter of $0.22 \mu \mathrm{m}$, were aseptically introduced into the medium, and simultaneously the test tubes were inoculated with the bacterial culture under 
scrutiny.

(3) Cultivation under aeration: in 250-ml Erlenmeyer flasks on a rotary shaker CERTOMAT BS-1 (B.Braun Biotech Int. GmbH, Germany) at $240 \mathrm{rpm}$ on a medium consisting of $(\mathrm{g} / \mathrm{l}):\left(\mathrm{NH}_{4}\right)_{2} \mathrm{SO}_{4}, 6.0 ; \mathrm{KH}_{2} \mathrm{PO}_{4}, 5.0 ; \mathrm{K}_{2} \mathrm{HPO}_{4}, 5.0 ; \mathrm{MgSO}_{4}, 0.2$; and $\mathrm{CaCO}_{3}$, 10.0, containing MGHPs (20 - $750 \mathrm{mg} / 1$ OCS; 6 - $22.5 \mathrm{~g} / \mathrm{l}$ TDG). Control parameters included the biomass growth, the change in $\mathrm{pH}$ of the culture broth, the presence of TDG, and the content of organochlorine substances.

The biomass growth was routinely monitored by measuring $\mathrm{D}_{540}$ with a Genesys 10S spectrophotometer (Thermo Electron Corp., USA).

Considering that chemical hydrolysis of organochlorine substances can proceed in water medium, the studies of microbial degradation of MGHPs were carried out in comparison with the control probe (with the process performed under the same conditions but without microorganisms).

\subsection{DNA extraction from bacterial cultures}

DNA was extracted from the culture samples using incubation with $0.75 \mathrm{ml}$ of $1 \%(\mathrm{w} / \mathrm{v})$ potassium ethyl xanthogenate containing 1\% SDS (w/v), $20 \mathrm{mM}$ EDTA, $100 \mathrm{mM}$ TRIS and $800 \mathrm{mM} \mathrm{CH}{ }_{3} \mathrm{COONH}_{4}, \mathrm{pH} 7.4\left(70{ }^{\circ} \mathrm{C}, 1 \mathrm{~h}\right)$, followed by vortexing (10 s), a second incubation $\left(4^{\circ} \mathrm{C}, 30 \mathrm{~min}\right)$ and centrifuging (17 $\left.530 \mathrm{x} \mathrm{g}, 4^{\circ} \mathrm{C}, 10 \mathrm{~min}\right)$. DNA was precipitated using $0.75 \mathrm{ml}$ of 2 -propanol $\left(22-24{ }^{\circ} \mathrm{C}, 10 \mathrm{~min}\right)$, pelleted (12 $000 \times g, 22-24^{\circ} \mathrm{C}, 10 \mathrm{~min}$ ), washed twice with $200 \mu$ of $70 \%$ (v/v) ethanol, air dried $\left(20-24{ }^{\circ} \mathrm{C}\right.$ ) and dissolved in 50-200 $\mu$ of $10 \mathrm{mM}$ TRIS, $1 \mathrm{mM}$ EDTA, pH 8.0 (TE buffer). The DNA isolates were further purified using Montage cartridges (Millipore, Billerica, CA, USA) and stored at $-20^{\circ} \mathrm{C}$ until amplification with polymerase chain reaction $(\mathrm{PCR})$.

\subsection{DNA amplification}

The primers were from Oligomer (Helsinki, Finland). Partial 16S rRNA genes were amplified from the culture samples using a forward primer 27F (5' AGAGTTTGATCCTGGCTCAG-3'; general bacterial primer; Lane 1991) and a reverse primer 1525R (5'-AAGGAGGTGATCCAGCC-3'). PCR was performed in 20 $\mu \mathrm{l}$ scale with $1 \mu \mathrm{l}$ of template DNA, $0.4 \mu \mathrm{M}$ of forward and reverse primers, $200 \mu \mathrm{M}$ of each deoxynucleoside triphosphate (dNTP, Sigma-Aldrich), $1 \mathrm{U}$ of MasterTaq polymerase (Eppendorf, Hamburg, Germany), 1 x MasterTaq polymerase buffer containing $1.5 \mathrm{mM} \mathrm{Mg}(\mathrm{OAc})_{2}, 0.5 \mathrm{x}$ Taq Master Enhancer (Eppendorf), and $3 \mathrm{~g} \mathrm{l}^{-1}$ BSA. A Thermo PCR Sprint (Milford, MA, USA) thermal cycler was used. The initial step in the temperature programme was $70^{\circ} \mathrm{C}(5 \mathrm{~min})$ and $94{ }^{\circ} \mathrm{C}(5 \mathrm{~min})$. DNA polymerase was added during the initial $70{ }^{\circ} \mathrm{C}$ period (hot start). The following denaturing, annealing and extension programmes were used: 9 cycles of $\left[94^{\circ} \mathrm{C}(45 \mathrm{~s})\right.$, 
$\left.57{ }^{\circ} \mathrm{C}(45 \mathrm{~s}), 68^{\circ} \mathrm{C}(2 \mathrm{~min})\right], 24$ cycles of $\left[94^{\circ} \mathrm{C}(45 \mathrm{~s}), 54{ }^{\circ} \mathrm{C}(45 \mathrm{~s}), 68^{\circ} \mathrm{C}(2 \mathrm{~min})\right]$ and $68{ }^{\circ} \mathrm{C}(7 \mathrm{~min})$. The formation of PCR products (approx. 1,500 bp) was checked using agarose gel electrophoresis. The PCR products were stored at $-20{ }^{\circ} \mathrm{C}$. Products used in cloning were stored for a maximum of $24 \mathrm{~h}$.

\subsection{Cloning and sequencing}

The cloning of amplified DNA was performed with a Qiagen PCR cloning kit (pDrive plasmid vector) at the Sequencing Laboratory of the Institute of Biotechnology, University of Helsinki. After a 24-h culturing bacterial pellets were lysed and plasmid DNA purified using 2-propanol precipitation and centrifuging, and stored in TE $\left(-20^{\circ} \mathrm{C}\right)$. The plasmids were further amplified with primers UP and RP (5'-TAACGCCAGGGTTTTCCCAGTCACGA-3' and 5' GTGAGCGGATAACAATTTCACACAGG-3'), amplifying the insert from the plasmid. The products were isolated, subjected to sequencing reactions (two directions; primers $\mathrm{t} 7$ and sp6; 5'-TAATACGACTCACTATAGGG-3' and 5'ATTTAGGTGACACTATAGAA-3') and sequenced (ABI3730 XL 48-capillary automated sequencer). Sequences without overlapping or unclear bases were subjected to preliminary analysis using the Basic Local Alignment Search Tool (BLAST) programme (National Center for Biotechnology Information, Bethesda, MD, USA).

\subsection{Chemicals}

A model mixture of mustard gas hydrolysis products was prepared by heating an aqueous mixture of $0.65 \mathrm{M}$ TDG (ICN $103039 \mathrm{RT}, 98 \%$ purity) and $0.65 \mathrm{M} \mathrm{HCl}$ at 90 ${ }^{\circ} \mathrm{C}$ for $8 \mathrm{~h}$. The resulting MGHPs mixture contained $2500 \pm 300 \mathrm{mg} / \mathrm{l} \mathrm{OCS}$ and $(0.57$ $\pm 0.01) \mathrm{M}$ TDG. Thiodiglycolic acid (TDGA), thioglycolic acid (TGA) and $\beta$ mercaptoethanol were obtained from Merck KgaA, Germany. All the chemicals were of the highest purity commercially available. [(2-hydroxyethyl)thio]acetic acid (HETA) was synthesized and purified according to Black et al. (1993).

\subsection{Analytical methods}

The quantitative determination of OCS was performed spectrophotometrically (Franke, 1967). Thiodiglycol, thiodiglycolic acid, [(2-hydroxyethyl)thio]acetic acid and thiodiglycol sulphoxide content were determined by reversed-phase HPLC on an HP 1090 Hewlett-Packard chromatograph under the following conditions: temperature $25{ }^{\circ} \mathrm{C}$, Luna (Phenomenex) column; flow rate $1.5 \mathrm{ml} / \mathrm{min}$; detection at $215 \mathrm{~nm}$; eluent 5\% acetonitrile and 0.1\% TFA (trifluoroacetic acid); sample volume $20 \mu 1$. 
Hydrolysis of MGHPs was also determined by measuring the release of chloride ions with a model 96-17 B combination electrode (Orion Research Inc., USA). The electrode was calibrated by adding known concentrations of sodium chloride standards to the mineral salts medium used in the experiments. Uninoculated flasks were run in each experiment as controls.

Thioglycolic acid was detected by using a Hewlett-Packard 1090 HPLC liquid chromatograph with a diode array detector (USA) equipped with a Vydac column (USA) 218TP54 (RP-18, 4.6×250 mm, particle size $5 \mu \mathrm{m}$ ) under isocratic conditions with $20 \mathrm{mM}$ tetrabutyl ammonium (TBA) buffered with $20 \mathrm{mM}$ Na phosphate $(\mathrm{pH}=6.0)$, containing $15 \%(\mathrm{v} / \mathrm{v})$ acetonitrile at $50{ }^{\circ} \mathrm{C}$. The flow rate was $1.5 \mathrm{ml} / \mathrm{min}$ and detection of the compounds was at $210 \mathrm{~nm}, 250 \mathrm{~nm}$, and $265 \mathrm{~nm}$. The injection volume was $10 \mu \mathrm{l}$ and the analysis lasted $10 \mathrm{~min}$.

Detection of $\beta$-mercaptoethanol after its modification by Elman (1959) was carried out on a Hewlett-Packard 1090 HPLC liquid chromatograph with UV Monitor Model 1740 BIO-RAD (USA) using Waters C-18 column, $(\Delta$-Pack, $3.9 \times 150 \mathrm{~mm}$, particle size $5 \mu \mathrm{m})$ gradient mode $(1.5 \mathrm{ml} / \mathrm{min})$. The eluents were: $\mathrm{A}, 0.1 \%$ TFA and B, $100 \%$ acetonitrile. For the analysis, the following linear gradient was used: from $20 \% \mathrm{~B}(0 \mathrm{~min}), 37 \% \mathrm{~B}(8.5 \mathrm{~min})$ at $20{ }^{\circ} \mathrm{C}$. The total analysis time was $12 \mathrm{~min}$. The compounds were detected at $313 \mathrm{~nm}$ and $338 \mathrm{~nm}$.

\subsection{Statistical analyses}

All statistical analyses were performed with Statistica software (version 6; Statsoft). The differences were considered significant at $\mathrm{P}<0.05$.

\section{Results and discussion}

\subsection{Effect of MGHPs on marine microbiota}

Over the last few decades microbiological studies have been carried out at the chemical munitions dump sites in the Baltic Sea. In 1994-2000, we monitored the ecological situation at the dump sites under the Marine Ecological Patrol Program. The analysis of the near-bottom water samples taken while we were sailing in the Skagerrak Strait, as well as near Liepaja and at the Bornholm dump site yielded $0.5 \bullet$ $10^{6}$ to $7.1 \cdot 10^{6}$ cells $/ \mathrm{ml}$ for the total amount of microbiota, 0.4 to $6.5 \mathrm{mg} / \mathrm{l}$ for bacterial biomass, and $0.2 \cdot 10^{4}-4.9 \cdot 10^{4}$ cells $/ \mathrm{ml}$ for the amount of heterotrophic microorganisms (Table 2).

At many stations significant amounts of bacterial cultures, able to grow in the medium containing mustard gas hydrolysis products (both chlorinated and nonchlorinated), were observed in the near-bottom water. However, there was no significant growth of these microorganisms following inoculation of water samples to 
the same agar medium without MGHPs. It was therefore concluded that the source of carbon for these bacteria were MGHPs. As Table 2 shows, at some stations they account for $20-98 \%$ of the total heterotrophic microbiota. No MGHP-degrading microorganisms were found in surface water layers and horizons $1 \mathrm{~m}$ above the sea bed. The formation of an enrichment culture of microorganisms at some of the observation stations can be due to the appearance in the environment of a new compound, mustard gas, acting as a selective agent. The largest number of "abnormal" sites was observed in the Bornholm Basin. MGHP-degrading microorganisms appeared at about $40 \%$ of stations in this area (Medvedeva et al., 1998).

In 2007, the microbiological studies were carried out in the Bornholm dump site area in the framework of the EC-FP6 project "MERCW" (Modelling of Environmental Risks Related to Sea-dumped Chemical Weapons). The studies focused on the primary dumping area located in the southern part of the Bornholm Basin, east of the island of Bornholm, in water depths ranging from 70 to over $95 \mathrm{~m}$ (Fig. 2). Four shipwrecks were identified in this area in 1994-2000 (Paka and Spiridonov, 2001). The wrecks were extensively damaged. One of the wrecks was covered by trawling nets, which were suspended in the water column above the wrecks by intact floats (Fig. 3A). Partly corroded artillery missiles were observed on the deck of the other wreck (Fig. 3B). The microbiological survey was undertaken in two research areas (Fig. 2): the first research area was in the vicinity of the shipwrecks and the second in the zone marked by the detection of chemical warfare agents on previous research trips (Paka, 2004).

Near-bottom water contained MGHP-degrading microorganisms that were up to $58 \%$ of the total number of heterotrophic microorganisms at more than a half of the stations (Fig. 4). Most of such "abnormal" points with a high concentration of MGHPdegrading microorganisms were detected in the first research area near the sunken ships. 7 "abnormal" points were found in the second research area, where CWA had been detected previously.

The "abnormal" sites of mustard gas possibly leaking into the environment differed from other stations in the species diversity of microorganisms (Table 3 ).

The microbiota of the near-bottom water out of the dump site $(30 \mathrm{~km})$ was represented by microorganisms predominantly of the genera Pseudomonas, Bacillus, Sphingomonas, Flavobacterium, Micrococcus, Alcaligenes, Achromobacter, with Pseudomonas and Bacillus genera dominating (the latter accounted for up to $25 \%$ of the total number of heterotrophs).

The primary dump site showed a reduced diversity of bacteria. At many stations the dominance of a minimal number of Pseudomonas, Bacillus, Arthrobacter, and Achromobacter species in near-bottom water was observed. The species diversity of the microbial population at the dump site was reduced compared with other sites, most probably because of an increase in the number of MGHP-degrading 
microorganisms. The reduction in the species diversity of bacterioplankton suggests a decrease in the stability of the biosystem as a whole.

\subsection{Isolation and characterization of MGHP-degrading microorganisms}

During the period 1994-2007, over 200 MGHP-degrading bacteria were obtained from the near-bottom water samples taken at the Gotland Basin, Skagerrak Strait, and Bornholm dump site. Three of the most active strains capable of utilizing mustard gas hydrolysis products, 75-1, 23-3 and 93-2, were obtained from the Bornholm dump site.

All three isolated bacterial strains were aerobic, oxidase and catalase-positive, two were gram-negative, and one was gram-positive. The gram-positive strain 23-3, established by phenotypic assays, underwent a rod-coccus morphological change. Strain $75-1$ was the gram-negative, nonmotile rod of $\sim 0.5$ by 1.5 to $2.0 \mu \mathrm{m}$. Strain 93-2 was the gram-negative, rod-shaped motile organism about 1.0 by $1.5 \mu \mathrm{m}$. Motility was imparted by a single polar flagellum. All three strains grew between $0{ }^{\circ} \mathrm{C}$ and $30{ }^{\circ} \mathrm{C}$, with the optimal growth temperature around $25^{\circ} \mathrm{C}$.

The 16S rRNA gene sequences (420-470 bp) showed the greatest similarities (99\%) with strain 75-1 and were related to those of the Achromobacter genera. Strain 23-3 was most closely related to bacteria from the genus Arthrobacter (with sequence similarities ranging from 98 to 99\%). The results indicated that strain 93-2 was phylogenetically closest to Pseudomonas.

The genera previously implicated in the degradation of mustard gas hydrolysis products include the genera Alcaligenes (Lee et al., 1996, Mulbry et al., 1998), Pseudomonas (Harvey et al., 1993; Medvedeva et al., 2007), and Micrococcus (Medvedeva et al., 2000). These bacteria have been isolated from contaminated terrestrial environments or from soil enrichment cultures by using mustard gas hydrolysis products. The present results indicate there are also marine MGHPdegrading bacteria of genera Arthrobacter, Achromobacter, and Pseudomonas. Although Achromobacter (also known as Alcaligenes) and Pseudomonas strains have been characterized as microorganisms capable of metabolizing the products of mustard gas hydrolysis, MGHP-degrading Arthrobacter has been found for the first time.

\subsection{MGHP-degradation range}

Comparative cultivation of degrader microorganisms was carried out (Table 4). The highest MGHPs-dechlorinating capability was exhibited by Achromobacter sp. 75-1. The maximum dechlorination rates were $26 \mathrm{mg}$ OCS/g biomass/day under static conditions, and under aeration, $37 \mathrm{mg}$ OCS/g biomass/day. All strains had shown lower dechlorination rates under static conditions than under aeration. The process of 
dechlorination was accompanied by evolution of the stoichiometric amount of mineral chlorine in the medium.

The degrader microorganisms also grew more actively under aeration. For example, the biomass gain for Achromobacter sp. 75-1 under aeration was 8 times that under static conditions. Figure 5 shows the dynamics of growth of Achromobacter sp. 75-1 in a medium supplemented with MGHPs as the sole carbon and energy source. The growth of microorganisms correlates with the decrease in thiodiglycol content. The complete utilization of MGHPs (60 mg OCS / and $0.18 \%$ TDG) is observed after 6 days.

Figure 6 shows the effect of different concentrations of mustard gas hydrolysis products on the bacterial growth under aeration. The growth of strain 75-1 (Fig. 6a) was proportional to the concentration of OCS up to $360 \mathrm{mg} / \mathrm{l}$ in the medium. However, concentrations above $360 \mathrm{mg} / \mathrm{l}$ induced a lag phase in bacterial growth. This effect was more pronounced at OCS concentrations above $500 \mathrm{mg} / \mathrm{l}$. Concentrations equal to or greater than $750 \mathrm{mg} / \mathrm{l}$ totally suppressed the growth.

Increasing concentrations of OCS adversely affected the biomass growth of both strain 93-2 (Fig. 6b) and strain 23-3 (Fig. 6c). The concentration of OCS also affected the lag phase before the beginning of TDG degradation by Arthrobacter sp. 23-3 and Pseudomonas sp. 93-2. The higher the concentration of OCS, the longer the lag phase lasted before the start of degradation (data not shown). The lag period before TDG degradation at high OCS concentrations was shown to be a lag phase in cell growth. Concentrations of OCS equal to or greater than $240 \mathrm{mg} / \mathrm{l}$ totally suppressed the growth of Arthrobacter sp. 23-3 and Pseudomonas sp. 93-2.

The highest specific growth rate $\left(\mu_{\max }\right)$ of 0.89 day $^{-1}$ was at $360 \mathrm{mg}$ of OCS/1 for strain Achromobacter sp. 75-1 (Fig. 7).

The highest growth rates for strains Arthrobacter sp. 23-3 and Pseudomonas sp. 93-2 were $0.76-0.73$ day $^{-1}$ at 120 and $60 \mathrm{mg}$ of OCS/l, respectively. The growth rates decreased in proportion to an increasing OCS concentration, and the lowest growth rate of $0.1 \mathrm{~h}^{-1}$ was observed at $730 \mathrm{mg}$ of OCS/1 (strain 75-1) and $260 \mathrm{mg}$ of OCS/1 (strains 93-2 and 23-3). The growth of strains 75-1, 93-2 and 23-3 is characterized by the peak of the maximum possible growth rate. Such growth is typical of the growth of microorganisms on a toxic substrate (Karasevitch, 1982).

The concentration of MGHPs produces a considerable effect on the process of the dechlorination of OCS, as well as on the growth of bacteria. The ultimate concentration of OCS (360 mg per litre) for the growth of Achromobacter sp. 75-1 corresponds to the highest rate of dechlorination. The increase in the concentration of OCS above this level leads to the sharp decrease in the rate of dechlorination as well as in the specific growth rate.

The growth rate of Arthrobacter sp. 23-3 and Pseudomonas sp. 93-2 reaches its maximum value at an OCS concentration of $60-120 \mathrm{mg} / \mathrm{l}$, but the most rapid dechlorination takes place at higher concentrations of the toxicant $(240 \mathrm{mg} / \mathrm{l})$. At this concentration the growth of bacteria is practically absent, and the whole substrate is 
consumed for energy of maintenance. The low maximum growth rate, long generation time and considerable outlays for the maintenance of both cultures are characteristic of the growth of microorganisms on toxic substrates (Pirt, 1975).

\subsection{Effect of environmental conditions on biodegradation}

The $\mathrm{pH}$ range for good growth of degrader bacteria under aeration is 7.0 to 8.0 (Fig. 8). There was little difference in growth in cultures with an initial $\mathrm{pH}$ between 6.0 and 8.0 (averaging about 20\%). The growth of Achromobacter sp. 75-11 and Arthrobacter sp. 23-3 was slightly more rapid at a neutral $\mathrm{pH}$. There was a gradual decrease in the growth rate of Arthrobacter sp. as the initial culture $\mathrm{pH}$ was increased from 8 to 9. Pseudomonas sp. 93-2 grew better in a slightly alkaline rather than acidic condition. The maximum growth rate of strain 93-2 was observed at $\mathrm{pH} 8$.

We found that the fastest growth of degrader-microorganisms occurred at 20 and $25{ }^{\circ} \mathrm{C}$ (Table 5). The growth rate at $20^{\circ} \mathrm{C}\left(\mu_{\max }=0.23-0.31 \mathrm{~g} / \mathrm{g} / \mathrm{d}\right)$ was about $3-5$ times more rapid than the growth rate at $5{ }^{\circ} \mathrm{C}$. Cultures also took longer to degrade TDG at $5{ }^{\circ} \mathrm{C}$ (Fig. 9, Fig. 10, Fig. 11). The time required for thiodiglycol degradation was 30-45 days at 20 and $25^{\circ} \mathrm{C}$, but 180-210 days were required to degrade TDG at 5 ${ }^{\circ} \mathrm{C}$. The temperature had little effect on the biomass yield (Y) of the degradermicroorganisms (Table 5). However, the data indicated that the optimum temperature for biomass yield was $20-25{ }^{\circ} \mathrm{C}$.

The ability of microorganisms to degrade thiodiglycol at a low temperature is particularly important in cold Baltic Sea conditions.

\subsection{Metabolic pathways}

The metabolic pathway for the degradation of MGHPs by marine bacteria was studied. The intermediate products from the growth of strains 93-2, 23-3, and 75-1 in the medium containing thiodiglycol as a source of carbon were analyzed to elucidate the possible pathways of degradation. The disappearance of TDG was accompanied by an accumulation of acids. HPLC analysis revealed thiodiglycolic acid (TDGA) and [(2-hydroxyethyl)thio]acetic acid (HETA) in the culture supernatants of all the strains (Fig. 12). Thiodiglycol sulphoxide was not detected.

The appearance of acid products suggests that biodegradation of TDG begins with oxidation of its primary alcoholic groups. Earlier, oxidation of the thiodiglycol molecule to TDGA by alcohol dehydrogenase was reported (Lee et al., 2000, Ermakova et al., 2002). Incubation of all strains for more than 7 days led to a decrease in HETA and TDGA concentrations to an undetectable level.

TGA and acetate were detected in the culture supernatant from the growth of all bacteria on the TDGA-containing medium, which suggests $\mathrm{C}-\mathrm{S}$ bond cleavage in TDGA to yield these products. $\beta$-mercaptoethanol was detected as an intermediate product of TDG transformation in only two strains: Pseudomonas sp. 93-2 and 
Achromobacter sp. 75-1.

These results indicate that the major pathway for TDG degradation by all the strains studied is the oxidation of its primary alcoholic groups to HETA, TDGA and TGA with the formation of acetate upon further transformation. This pathway for TDG degradation is similar to that reported earlier for Alcaligenes and Pseudomonas (Lee et al., 2000; Garcia-Ruiz et al., 2002, Medvedeva et al., 2006). However, the formation of $\beta$-mercaptoethanol was detected for Pseudomonas sp. 93-2 and Achromobacter sp. 75-1. Previously, this intermediate product has also been detected among the products of TDG transformation by soil bacterium Pseudomonas sp. (Medvedeva et al., 2007). Thus, the results suggest two possible pathways of the TDG biodegradation, one of which yields HETA, TDGA and TGA, and the other, $\beta$ mercaptoethanol, which is further transformed to TGA (Fig. 13).

\section{Conclusions}

Microbiological analysis of near-bottom water samples near the sea bed of the dump sites for chemical weapons in the Baltic Sea revealed high levels of microorganisms able to use mustard gas hydrolysis products as source of carbon especially at the Bornholm dump site, as well as in the Gotland Deep, and at the Skagerrak dump site. The "abnormal" sites showed reduced diversity of microbiota. High numbers of MGHP-degrading microorganisms in near-bottom water indicate a possible leakage of $\mathrm{CW}$ agents into the environment and contamination of water and sediments with mustard gas and products of its hydrolysis in the research areas.

Bacterial cultures isolated from near-bottom water were able, with differing biodegradation rates, to dechlorinate and utilize mustard gas hydrolysis products as the source of carbon. The Arthrobacter, Achromobacter and Pseudomonas genera cultures were the most active. The main features of Arthrobacter sp. 23-3, Achromobacter sp. 75-1, and Pseudomonas sp. 93-2 are the tolerance to mustard gas hydrolysis products, and the ability to degrade a high concentration of OCS. They can use thiodiglycol as the sole source of carbon and energy. The isolated bacteria can completely dechlorinate OCS at up to $750 \mathrm{mg} / \mathrm{l}$ in $4-9$ days. But the complete utilization of the products of hydrolysis (mainly thiodiglycol) is observed at lower concentrations of OCS in the medium (up to $360 \mathrm{mg}$ ). The major pathway of TDG degradation was oxidation to HETA, TDGA and TGA plus eventual formation of acetate. The degradation of TDG by Pseudomonas sp. and Achromobacter sp. 75-1 can also occur via $\mathrm{C}-\mathrm{S}$ bond cleavage yielding $\beta$ mercaptoethanol. The microorganisms cannot only detoxify the contaminants, but also utilize them completely. The rate of biodegradation of mustard gas hydrolysis was temperaturedependent but also occurred at low temperatures.

The ability of microorganisms to carry out the mineralization of thiodiglycol at a low temperature is important for the marine environment, particularly for the dump sites, where water temperatures rarely exceed $7^{\circ} \mathrm{C}$. The results suggest the potential 
for self-purification of contaminated water and sediments by natural populations of microorganisms.

\section{Acknowledgements}

The studies were financially supported by the EC-FP6 project MERCW "Modelling of Ecological Risks Related to Sea-Dumped Chemical Weapons" (Contract Nr. INCO-CT2005-013408). The authors wish to thank Director Lars Paulin (Institute of Biotechnology, sequencing laboratory, Helsinki, Finland) for laboratory and sequencing facilities and Mr. Janne Härkönen for assistance with cloning and sequencing work. The authors thank Mr. Evgenii Protasov for the highperformance liquid chromatography analyses and helpful discussions.

\section{References}

Åstot, C., Hägglund, L., Nilsson, C., 2007. World War I Gas Bomb Found in Harbour Pool. Abstracts of the 9th International Symposium on Protection against Chemical and Biological Warfare Agents (Gothenburg, Sweden, 22-25 May, 2007): 169.

Beaudry, W.T., Bossle, P.C., Harvey, S.P., Kolakowski, J.E., Procell, L.R., et al., 1995. Neutralization/biodegradation of HD. In: Analytical Methods for Environmental Sampling of Chemical Warfare Agents and Their Degradation Products (Watson AP, Kistner SL, eds). ORNL/M-4315. Oak Ridge, TN:Oak Ridge National Laboratory.

Black, R.M., Brewstar, K., Clarke, R.J., Hambrook, J.L., Harrison, J.M., Howells, D.J., 1993. Metabolism of thiodiglycol (2,2'thiobis-ethanol): isolation and identification of urinary metabolites following intraperitoneal administration to rats. Xenobiotica 23, 473-481.

Chemical munitions in the Southern and Western Baltic Sea. Complication, assessment and recommendations. 1993. Federal Maritime and Hydrographic agency, Hamburg, Germany.

Ellman, G.L., 1959. Tissue sulphydryl groups. Archives of Biochemistry and Biophysics 82, 70-77.

Ermakova, I.T., Starovoitov, I.I., Tikhonova, E.B., Slepen'kin, A.V., et al.., 2002. Bioutilization of tiodiglycol, the product of mustard detoxification: isolation of degrading strains, study of biodegradation process and metabolic pathways. Process Biochemistry 38, 31-39.

Franke S., 1967. Lehrbuch der Militarchemie. Berlin: Deutscher Militarverlag, B.1, 440 (Dutch).

Glasby, G.P., 1997. Disposal of Chemical Weapons in the Baltic Sea. The Science of the Total Environment. 206, 267-273.

Garcia-Ruiz, V., Martin-Otero, L. E., and Puyet, A., 2002. Transformation of 
thiodiglycol by resting cells of Alcaligenes xylosoxidans PGH 10. Biotechnology Progress 18, 252 - 256.

Harvey, S.P., DeFrank, J.J., 1993. Biodegradation of chemical warfare agents: demilitarization applications, in: Kamely, D., Sasmore, R. (Eds.), Army science: The New Frontiers, Military and Civilian Application, Woodlands TX: Borg Biomedical Services.

HELCOM, 1993. Chemical munitions in the southern and western Baltic Sea compilation, assessment and recommendations. Federal Maritime and Hydrographic Agency, Hamburg, Germany, May 1993.

HELCOM, 1994. Report on Chemical Munitions Dumped in the Baltic Sea, Report to the 16th Meeting of the Helsinki Commission 8-11th March 1994 from the Ad Hoc Working Group on Dumped Chemical Munitions, HELCOM CHEMU.

HELCOM, 1996. Third Periodic Assessment of the State of the Marine Environment of the Baltic Sea, 1989-1993. Executive Summary. Balt. Sea Envir. Proc. No 64.

HELCOM, 2005. Press release regarding chemical weapons dumps in the Baltic. Helsinki Commission, May 2.

www.helcom.fi/press_office/news_helcom/en_GB/ChemicalMunitions1115039886140/.

Karasevitch, Ju.N., 1982. Osnovi selekzii microorganizmov, utilizirujushich sinteticheskiye organicheskiye soedineniya [Fundamental of Selection of Synthetic Organic Substances Utilizing Microorganisms], Nauka, Moscow, 144.

Kilbane, J.J., Jackowski, K., 1996. Biocatalytic detoxification of 2-chloroethyl ethyl sulfide. Journal of Chemical Technology \& Biotechnology 65, 370 - 374.

Kuznetsov, C.I., Dubinina, G.A., 1989. Metody izucheniya vodnykh mikroorganizmov (Methods of studying aquatic microorganisms), Moscow, Nauka, 286 (in Russian).

Lee, T.S., Pham, M.Q., Weigand, W.A., Harvey, S.P., Bentley, W.E., 1996. Bioreactor strategies for the treatment of growth inhibitory waste: an analysis of thiodiglycol degradation, the main hydrolysis product of sulfur mustard. Biotechnology Progress 12, 533 - 539.

Lee, T.S., Chan, S.H., Weigand, W.A., Bentley, W.E., 2000. Biocatalytic transformation of [(2-Hydroxyethyl)thio]acetic acid and thiodiglycolic acid from thiodiglycol by Alcaligenes xylosoxidans ssp. xylosoxidans (SH91). Biotechnology Progress 16, 363-367.

Medvedeva, N.G., Spiridonov M.A., Polyak, Yu.M., Gridneva, Yu.A., Zaytseva, T.B., Ribalko, A.E. 1998. Ecological inspections of the Baltic Sea chemical weapon dump sites. Ecological Chemistry 7, 20-26 (in Russian).

Medvedeva, N.G., Zaytseva, T.B., Zinovieva, S.V., Sukharevich, V.I., Orlova, O.G. 2006. Destruction of mustard gas hydrolysis products by Pseudomonas sp. Y 13. Biotekhnologiya 2, 50-56 (in Russian).

Medvedeva, N., Polyak, Y., Zaytceva, T., Zinovieva, S., 2000. Microbiological destruction of mustard in soil, in: Wise, D.D., Trantolo, D.J., Cichon, E.J., et.al. (Eds.), Bioremediation of contaminated soils, Marcel Dekker, New York - 
Basel, pp. 151-176.

Medvedeva, N., Polyak, Yu., Zaytseva, T., Zinovieva, S., 2007. Soil bacterium Pseudomonas sp.: destroyer of mustard gas hydrolysis products. Biotechnology Journal 2, 1033-1039.

Medvedeva, N., Polyak, Yu., Kuzikova, I., Orlova, O., Zharikov, G., 2008. The effect of mustard gas on the biological activity of soil. Environmental Research 6, 289 -295 .

Mulbry, W., Rainina, E., 1998. Biodegradation of chemical warfare agents. ASM news 64, 325-331.

Munro, N.B., Talmage, S.S., Griffin, G.D., Waters, L.C., et al., 1999. The sources, fate, and toxicity of chemical warfare agent degradation products. Environmental Health Perspectives 107, 933-973.

Oldenhuis, R., 1992. Microbial Degradation of Chlorinated Compounds: Application of Specialized Bacteria in Treatment of Contaminated soil and Waste Water, Groningen, $214 \mathrm{p}$.

Opresko, D.M., Young, R.A., Faust, R.A., Talmage, S.S., Watson, A.P., Ross, R.H., Davidson, K.A., King, J., 1998. Chemical warfare agents: estimating oral reference doses. Reviews of Environmental Contamination \& Toxicology 156, $1-184$.

Paka, V., Spiridonov, M., 2001. Research of dumped chemical weapons made by R/V "Professor Shtokman" in the Gotland, Bornholm \& Skagerrak dumpsites, in: Missiaen,T., Henriet, J.-P. (Eds.), Chemical Munition Dump Sites in Coastal Environments, pp. 27-42.

Paka, V., 2004. Sea-dumped chemical weapons: state of problem. Russian Chemical Journal (Journal of Mendeleev Russian Chemical Society) XLVIII (2), 99-109.

Papirmeister, B., Feister, A.F., Robinson, S.I., et al., 1991. Medical defense against mustard gas: Toxic mechanisms and pharmacological implications, CRC Press, Boca Raton, FL.

Pirt, C.J., 1975. Principles of Microbe and Cell Cultivation, Blackwell Scientific Publications, London, 287.

Schulz-Ohlberg, J., Lemke, W., and Tauber, F., 2001. Tracing dumped chemical munitions in Pomeranian Bay (Baltic Sea) at former transport routes to the dumping areas off Bornholm Island, in: Missiaen, T., Henriet, J.-P. (Eds), Chemical Munition Dumpsites in Coastal Environments, pp. 43-52.

Tsyban A.V., 1980. Rukovodstvo po metodam biologicheskogo analiza morskoi vody i donnykh otlozhenii (Manual on methods of biological analysis of seawater and bottom sediments), Gidrometeoizdat, Leningrad, 192 (in Russian).

Wariishi, H., Itoh, N., Yoshida, M., Miyamoto, T., Tanaka, H., 2002. Complete degradation of yperite, a chemical warfare agent, by basidiomycetes. Biotechnology Letters 24, 501-505.

Yang, Y.C., Baker, J.A., Ward, J.R., 1992. Decontamination of chemical warfare agents. Chemical Reviews 2, 1729-1743. 
641

\section{Figure legends}

Fig. 1 - Dump site locations map: (A) the Bornholm site; (B) the Gotland Deep site; (C) the Skagerrack site

Fig. 2 - Location of the chemical munitions dump site at the Bornholm Basin. The circle marks the primary dump site area; the rectangle marks the larger dump site boundary. 1: the first research area, 2: the second research area

Fig. 3 - Images of the shipwrecks at the Bornholm dump site (after Paka and Spridonov, 2001). A: wreck covered with fishing nets. B: missile found on the deck of the wreck

Fig. 4 - Concentration of MGHP-degrading microorganisms (mean $\pm \mathrm{SD}$ ) present at the primary dump site within the first research area (1), within the second research area (2), and out of the primary dump site (3)

Fig. 5 - Growth and utilization of TDG by Achromobacter sp. 75-1. The data are means \pm SD of three independent measurements.

Fig. 6 - Effect of MGHPs concentrations on the growth of Achromobacter sp. 75-1 (a), Arthrobacter sp. 23-3 (b), and Pseudomonas sp. 93-2 (c).

Fig. 7 - Effect of OCS on dechlorination rate (A) and growth rate (B) of Achromobacter sp. 70-11, Arthrobacter sp. 41-3 and Pseudomonas sp. 3-1. The data are means \pm SD of three independent measurements.

Fig. 8 - Effect of pH on growth of Achromobacter sp. 75-1, Arthrobacter sp. 23-3 and Pseudomonas sp. $93-2\left(25^{\circ} \mathrm{C}\right)$. The data are means $\pm \mathrm{SD}(\mathrm{n}=3)$.

Fig. 9 - Effect of temperature on degradation of TDG by Achromobacter sp. 75-1 under static conditions: (a) TDG concentration; (b) biomass growth $\left(\mathrm{OD}_{540}\right)$. The symbols indicate the means of triplicate experiments. Vertical bars indicate standard deviations.

Fig. 10 - Effect of temperature on degradation of TDG by Arthrobacter sp. 23-3 under static conditions: (a) TDG concentration; (b) biomass growth $\left(\mathrm{OD}_{540}\right)$. The symbols indicate the means of triplicate experiments. Vertical bars indicate standard deviations.

Fig. 11 - Effect of temperature on degradation of TDG by Pseudomonas sp. 93-2 under static conditions: (a) TDG concentration; (b) biomass growth $\left(\mathrm{OD}_{540}\right)$. The 
661 symbols indicate the means of triplicate experiments. Vertical bars indicate standard 662 deviations.

663

664

665

666

667

668
Fig 12 - HPLC chromatogram of Arthrobacter sp. 23-3 supernatant: (1) at initiation of the incubation in TDG-containing media; (2) after 72 hours of incubation

Fig. 13 - Metabolic pathways for TDG utilization by bacteria isolated from the Baltic Sea 
ACCEPTED MANUSCRIPT

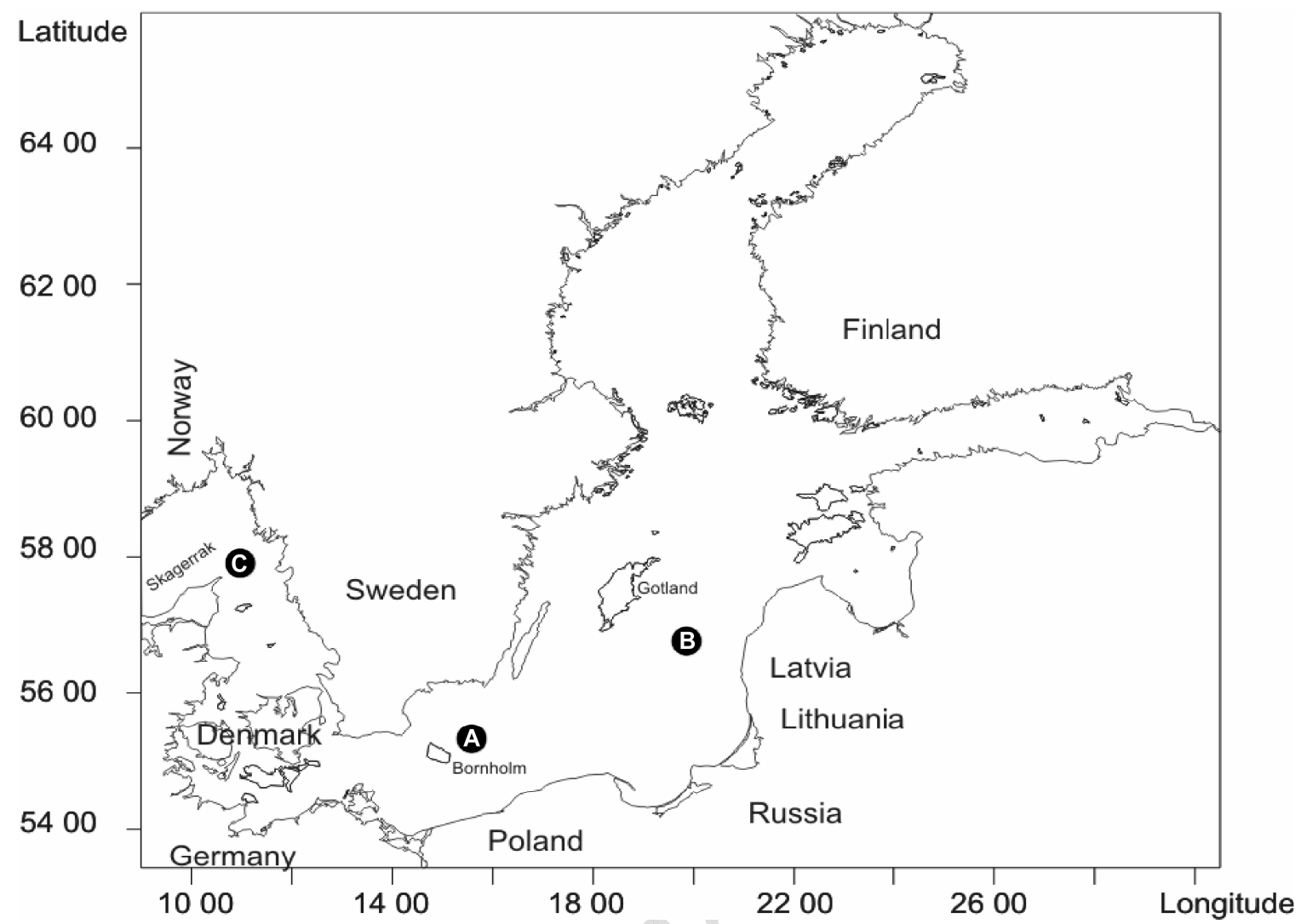



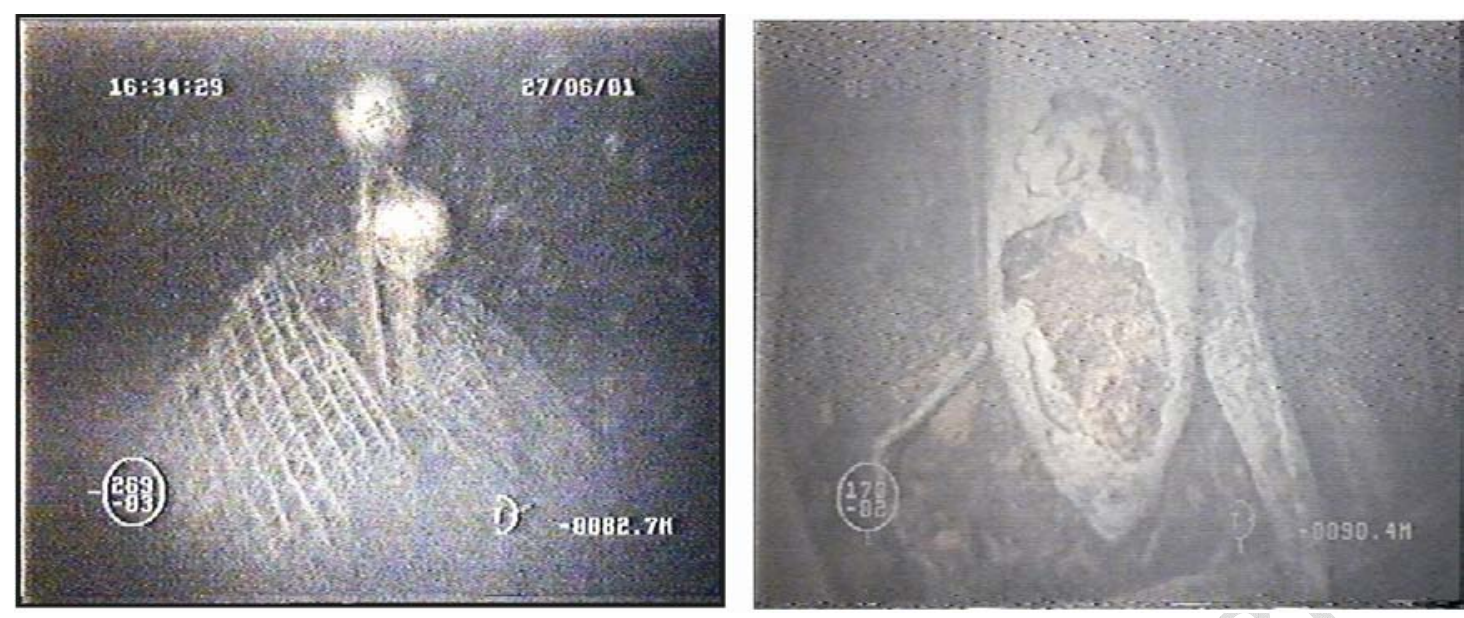


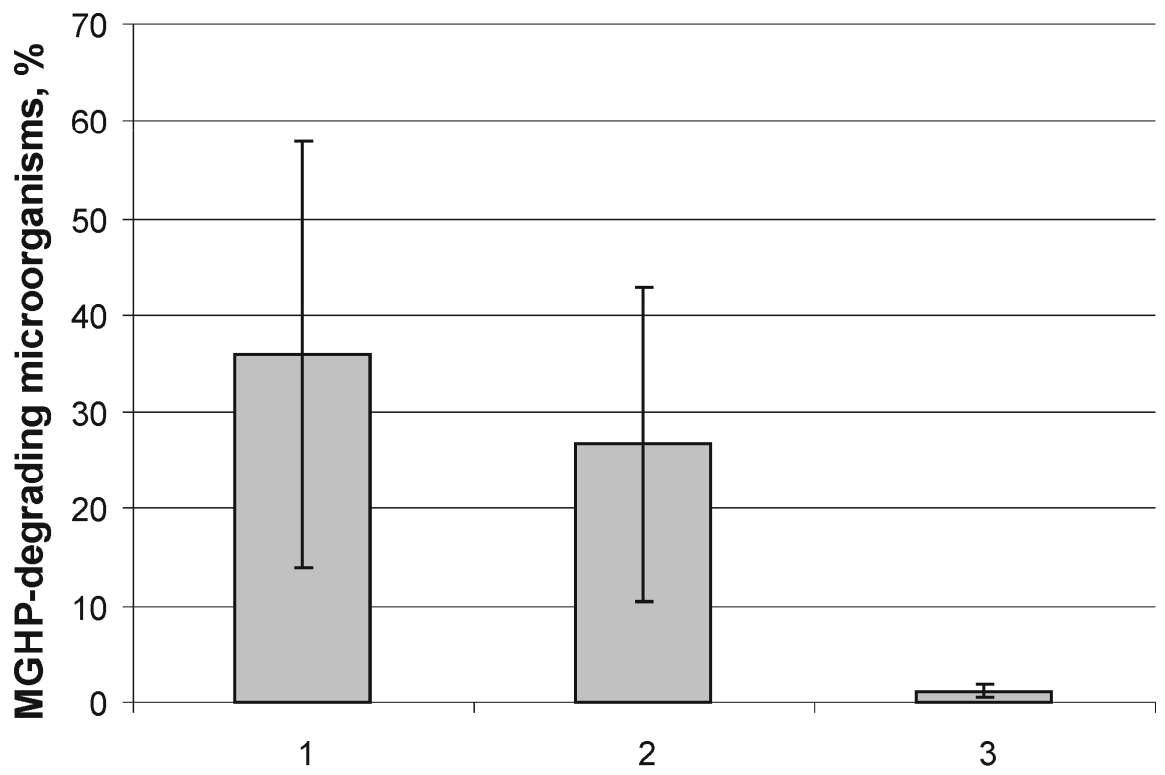


$\rightarrow$ Biomass, g/l $\_$TDG

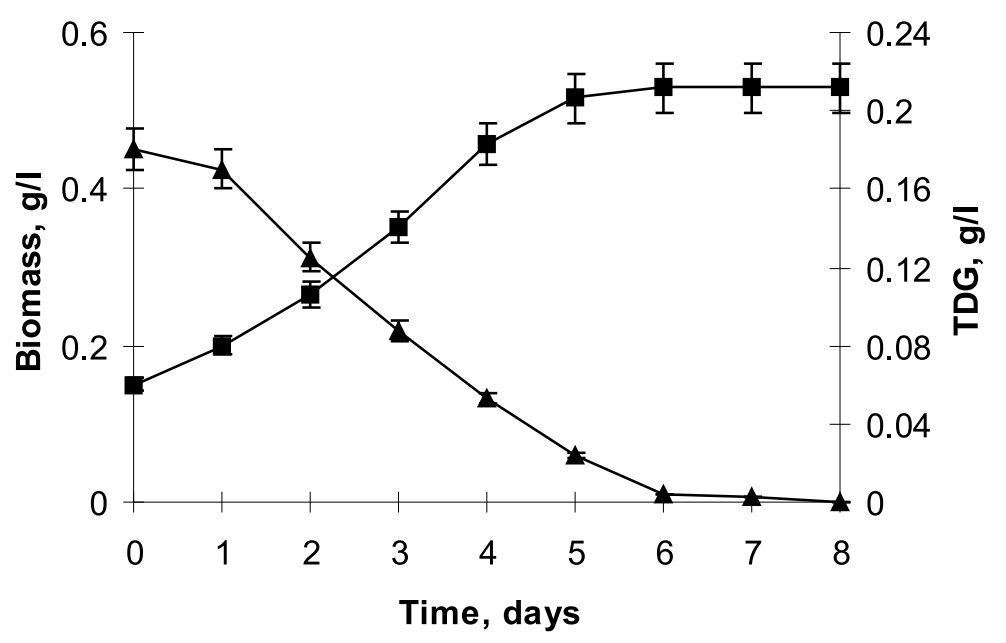


a

$\longrightarrow 200 \mathrm{mg}$ OCS/l; $6 \mathrm{~g} / \mathrm{l} \mathrm{TDG} \rightarrow-360 \mathrm{mg}$ OCS/l; $10.8 \mathrm{~g} / \mathrm{l} \mathrm{TDG}$

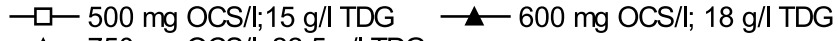

$\neg-750 \mathrm{mg}$ OCS/l; $22.5 \mathrm{~g} / \mathrm{l} \mathrm{TDG}$

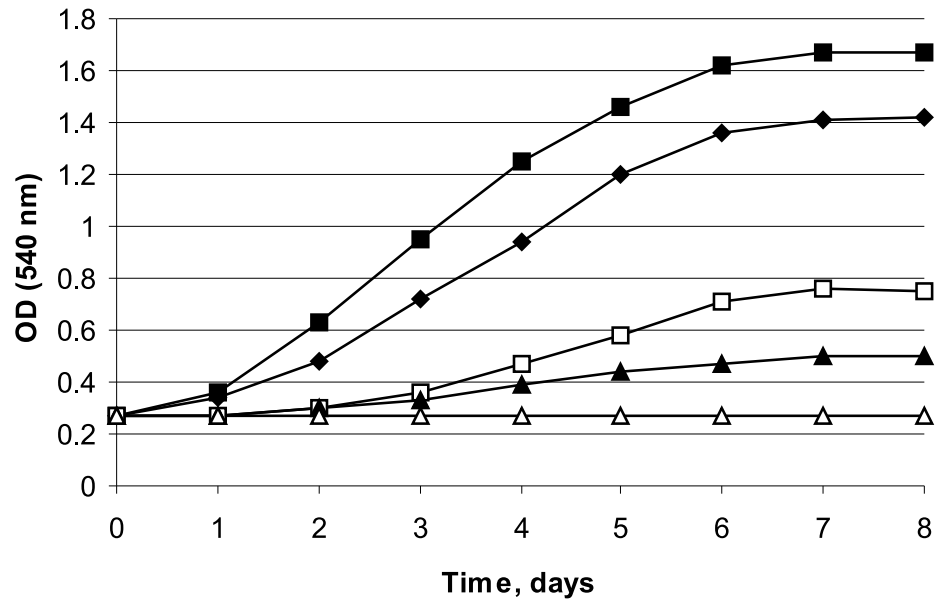




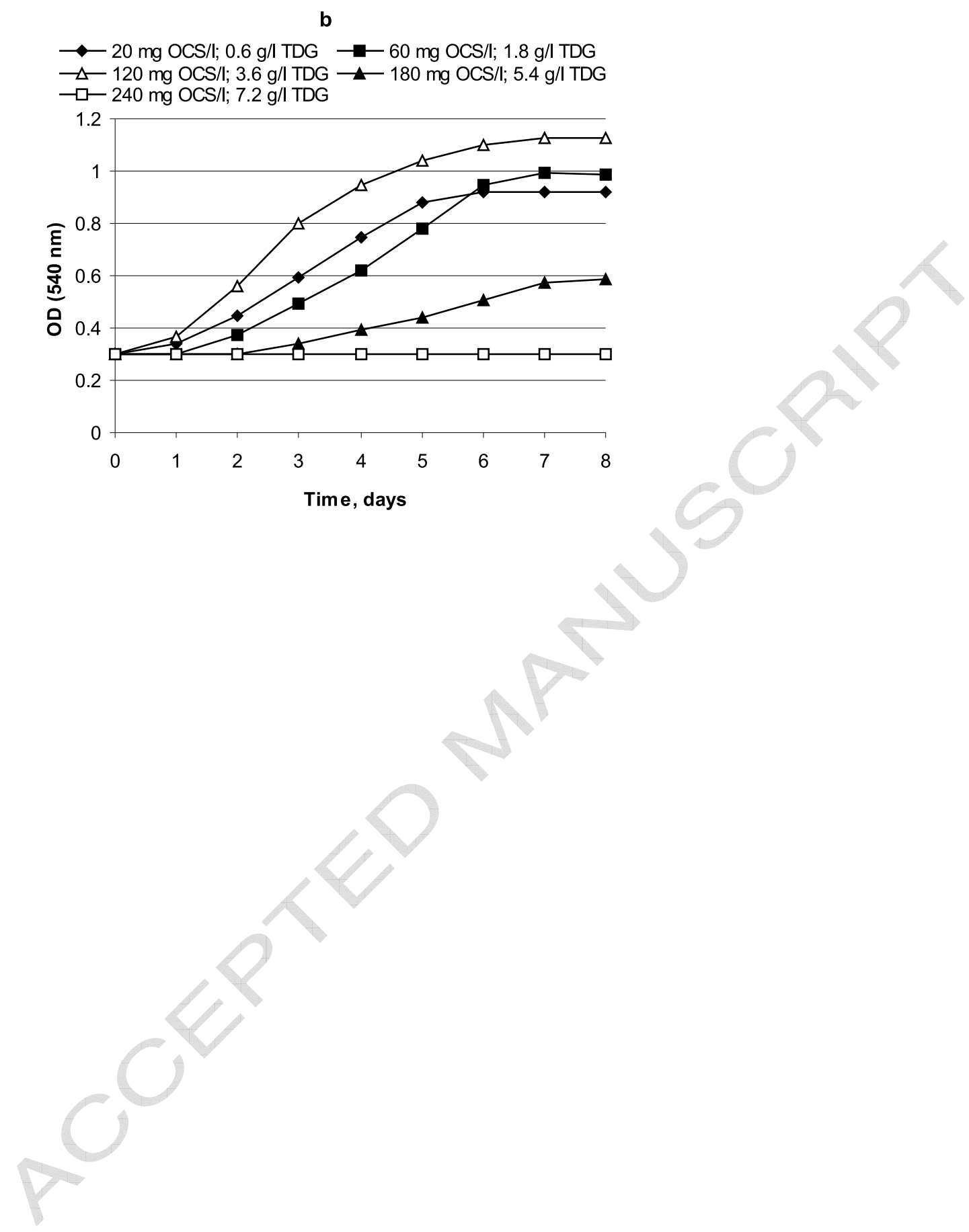


C
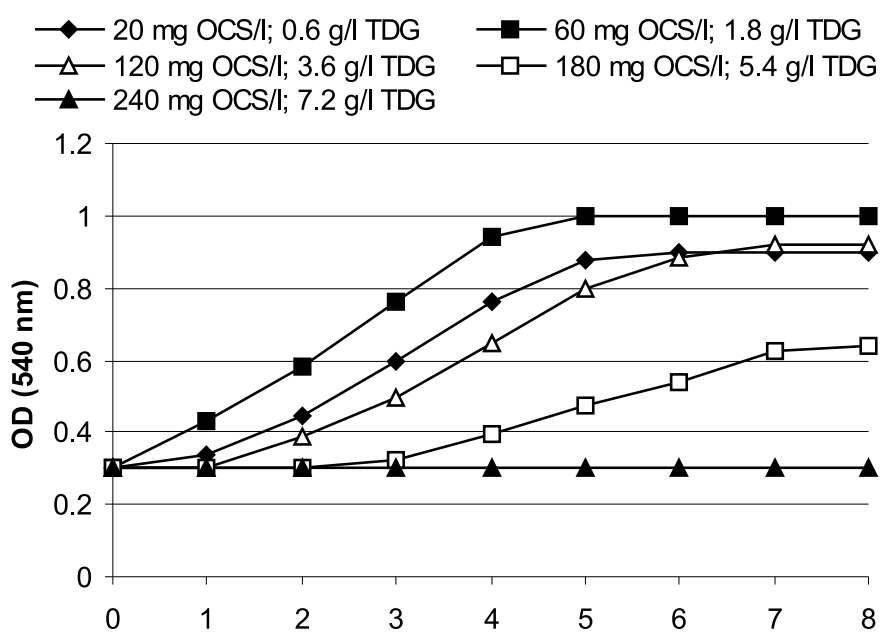

Time, days 


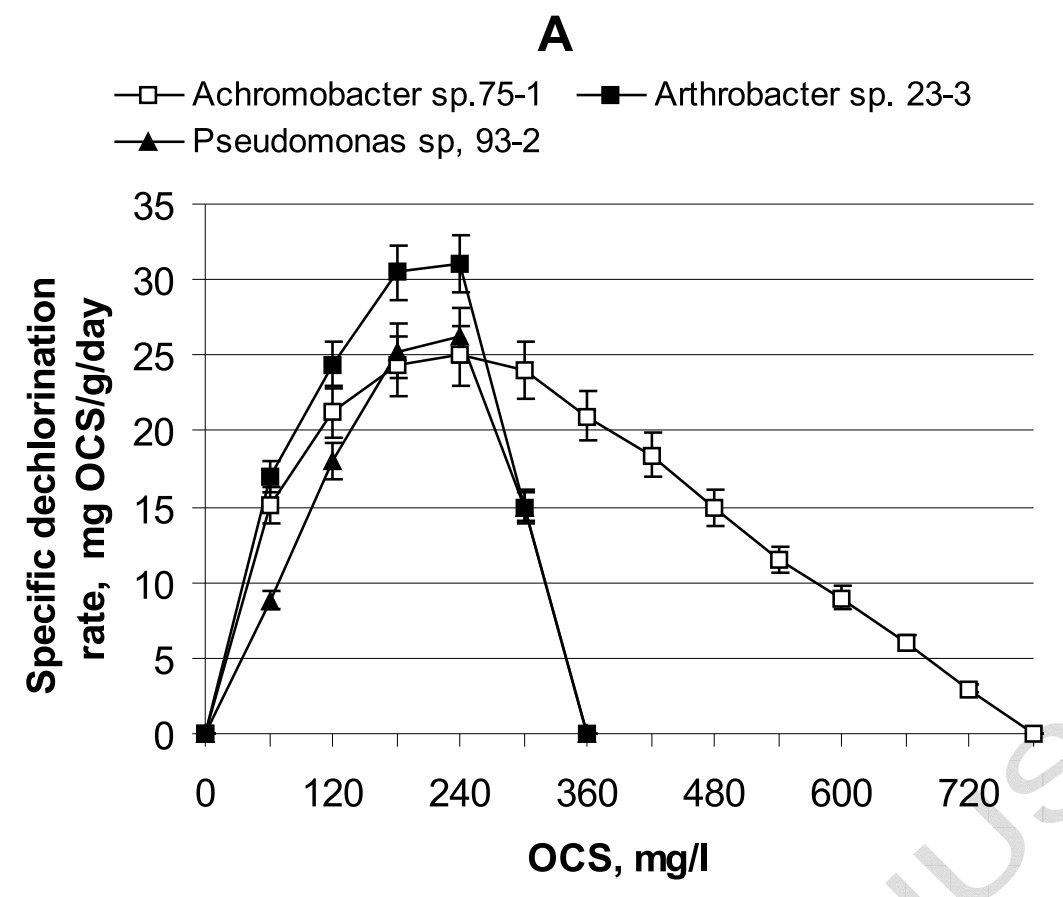




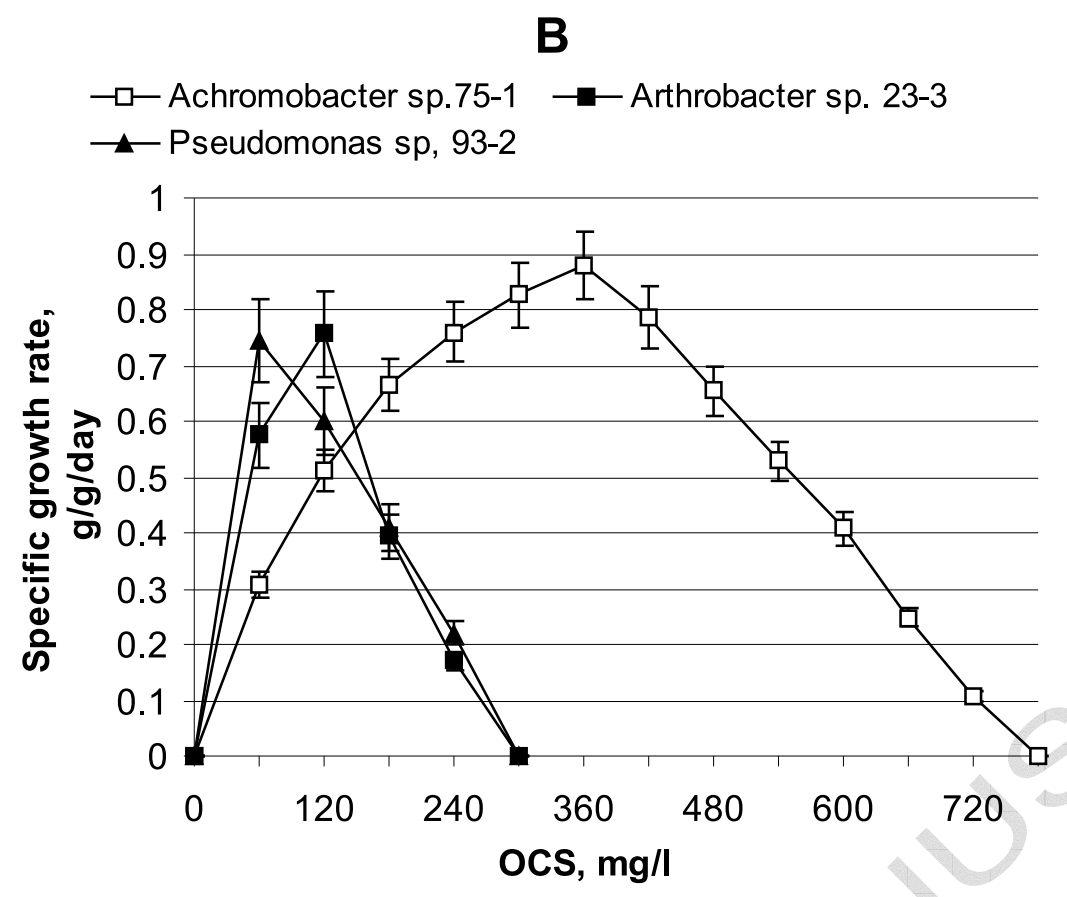




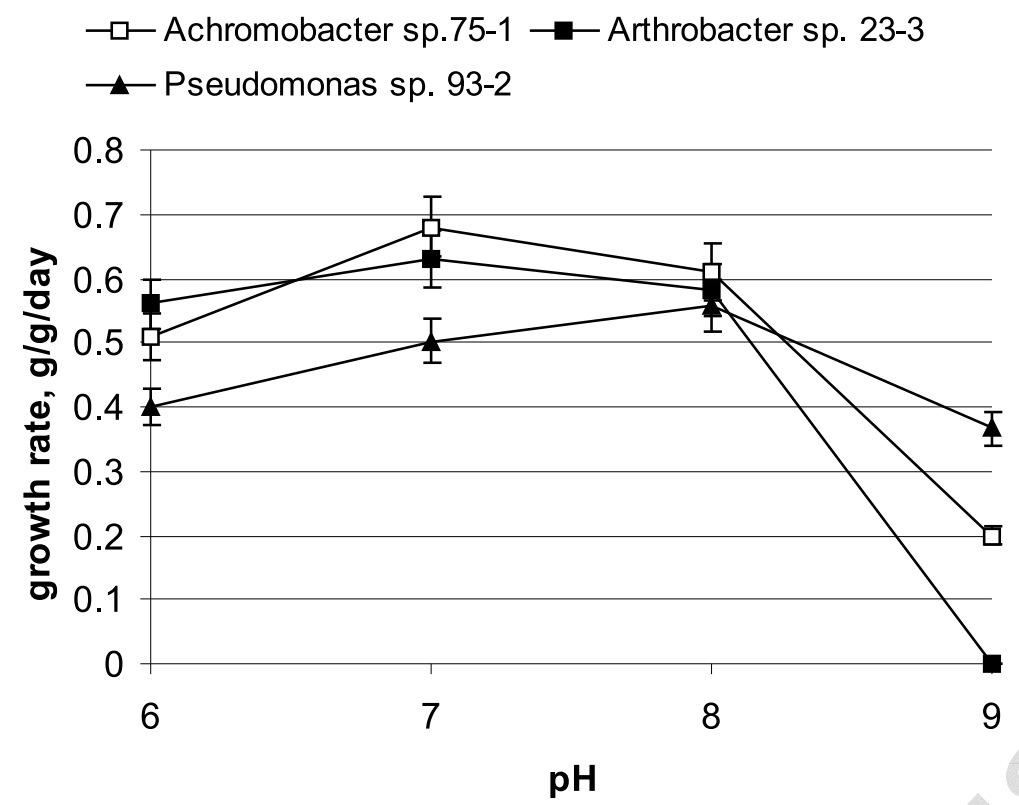




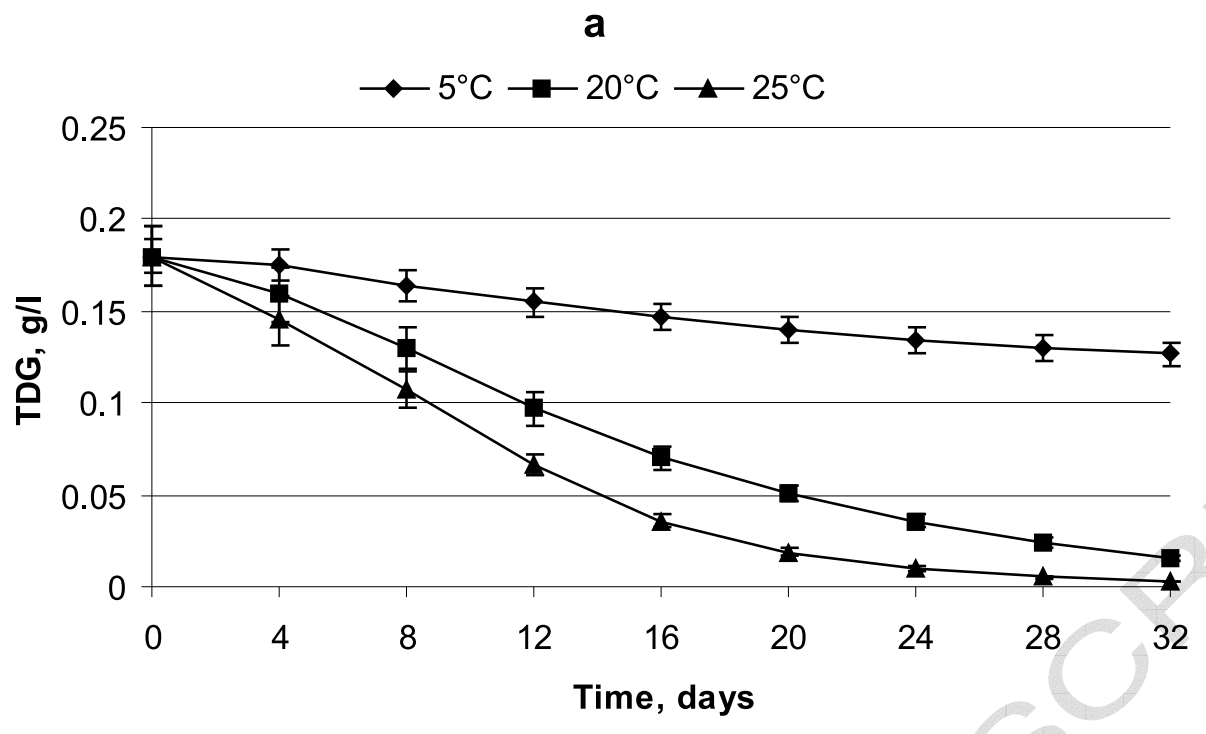


b

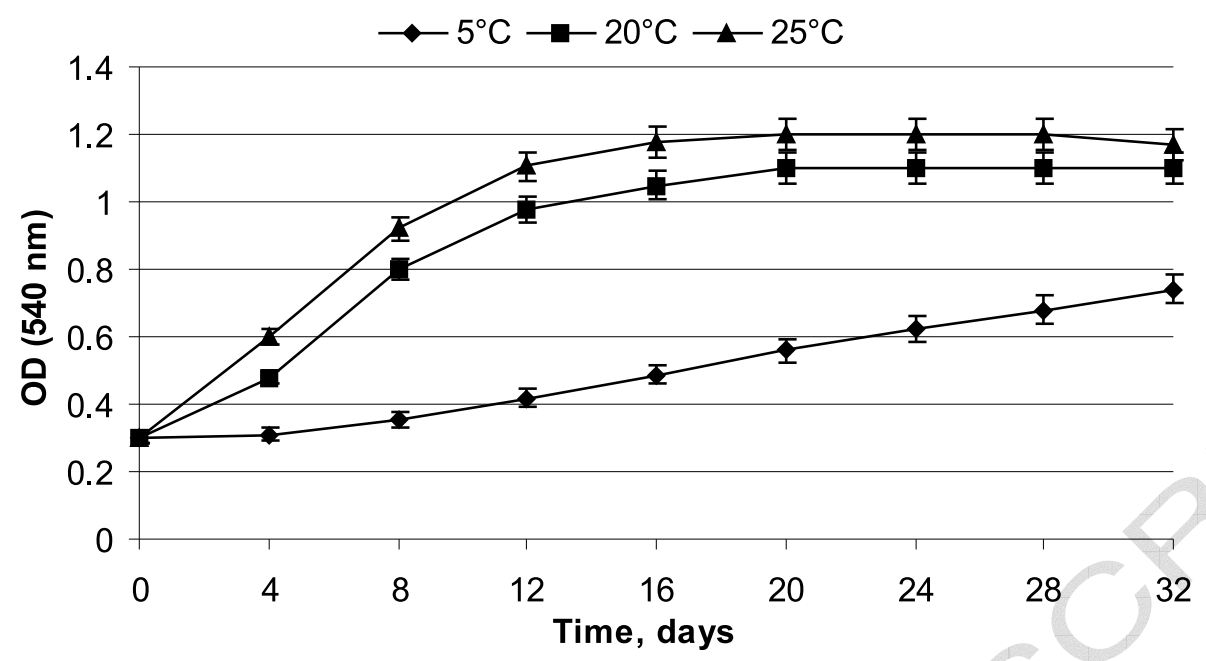




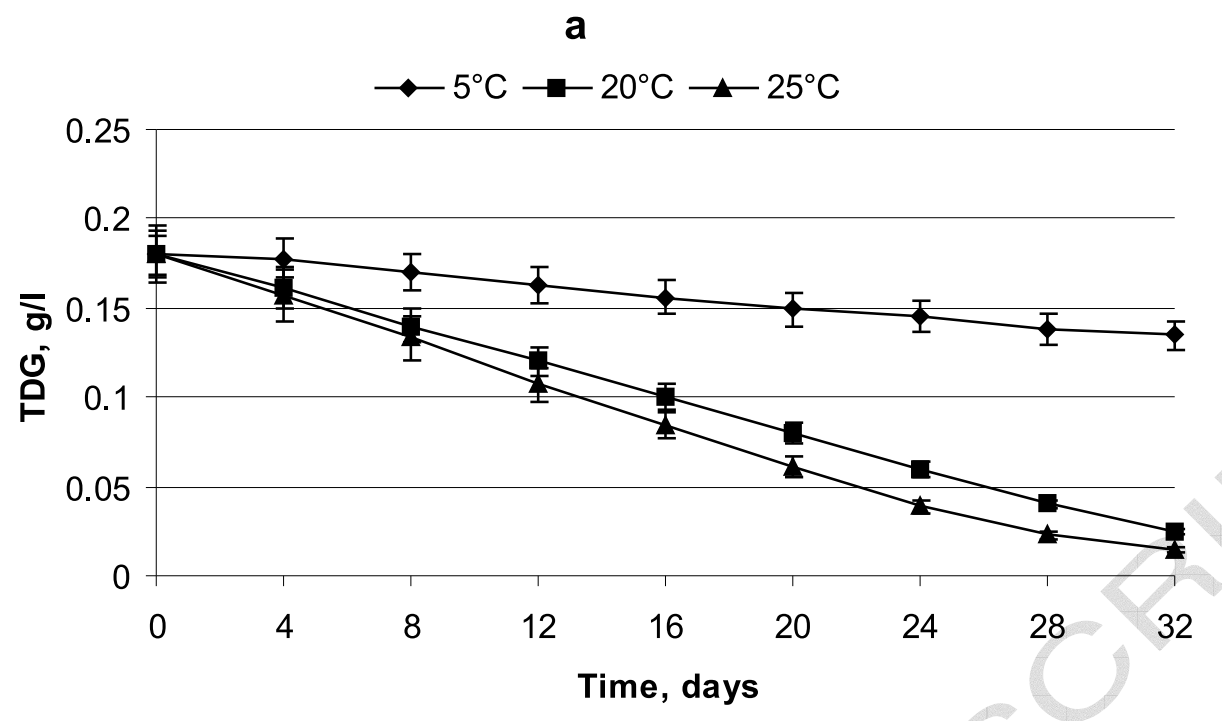


b

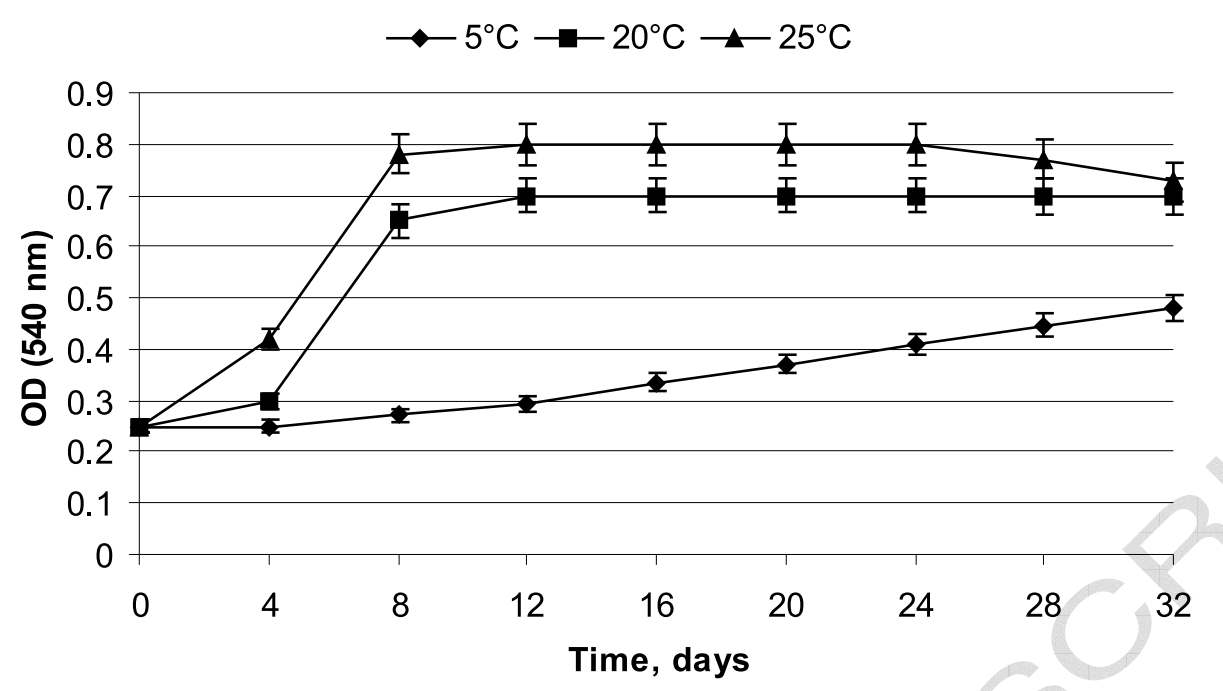




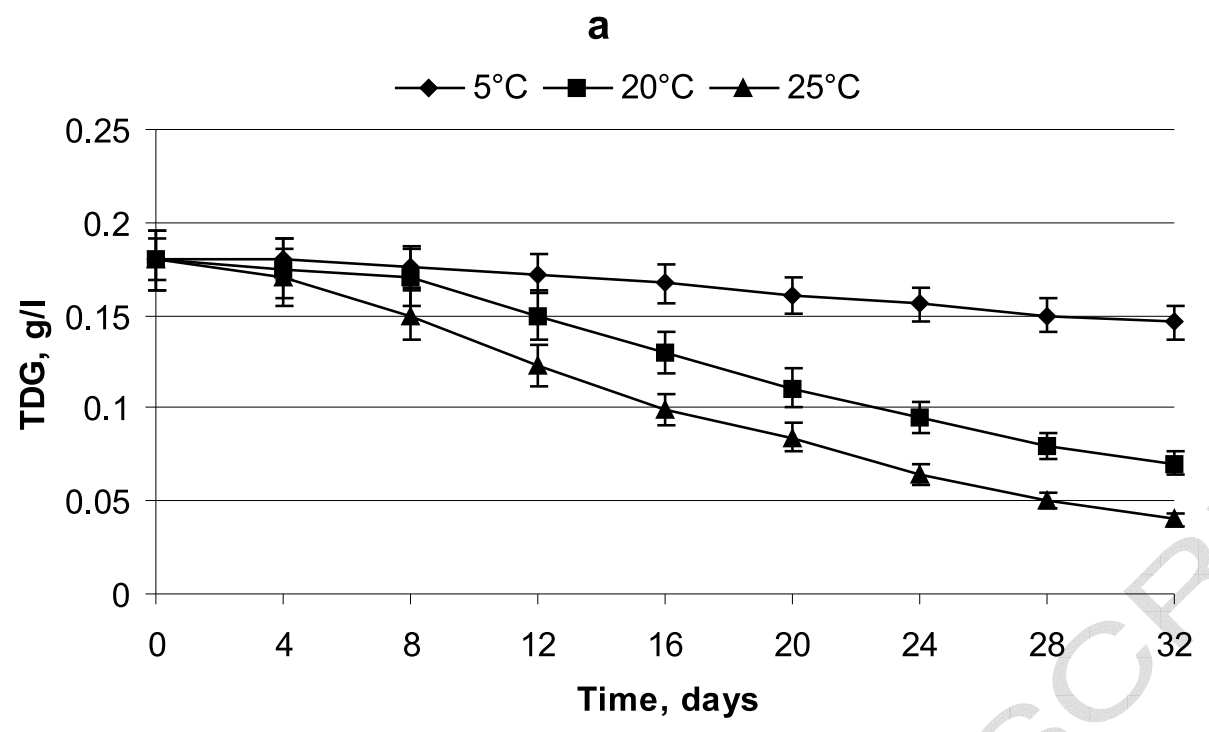




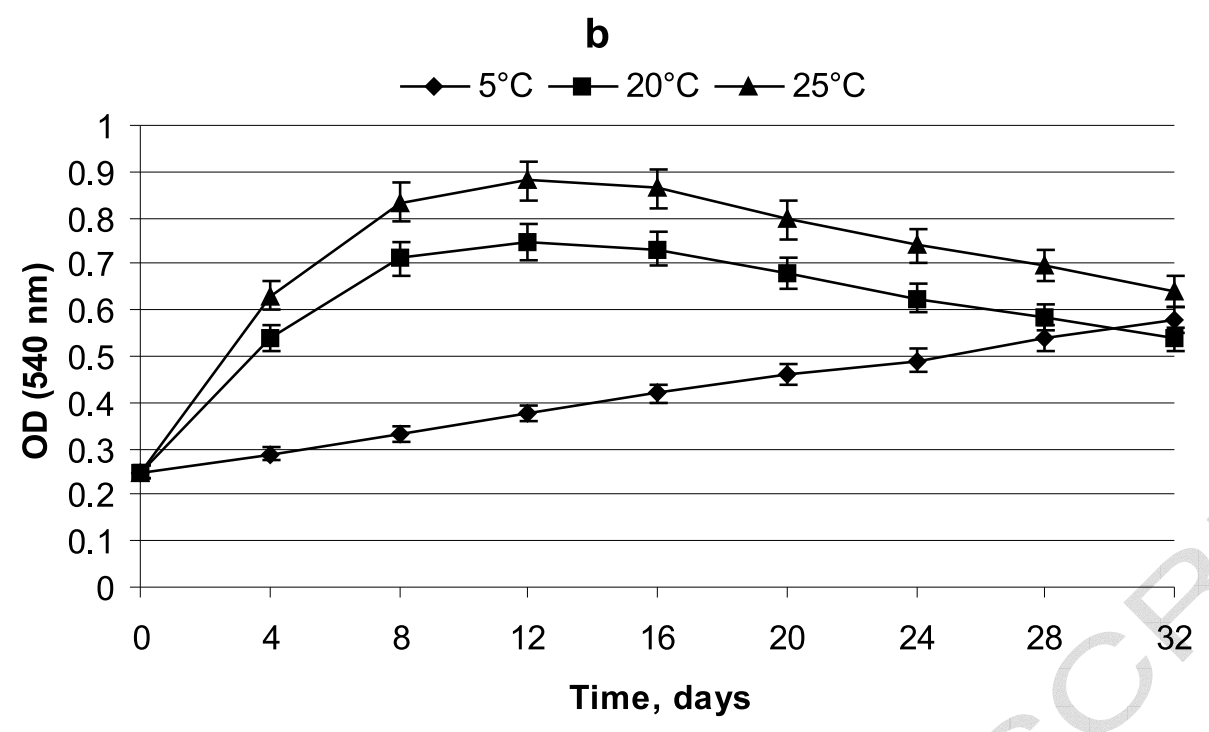




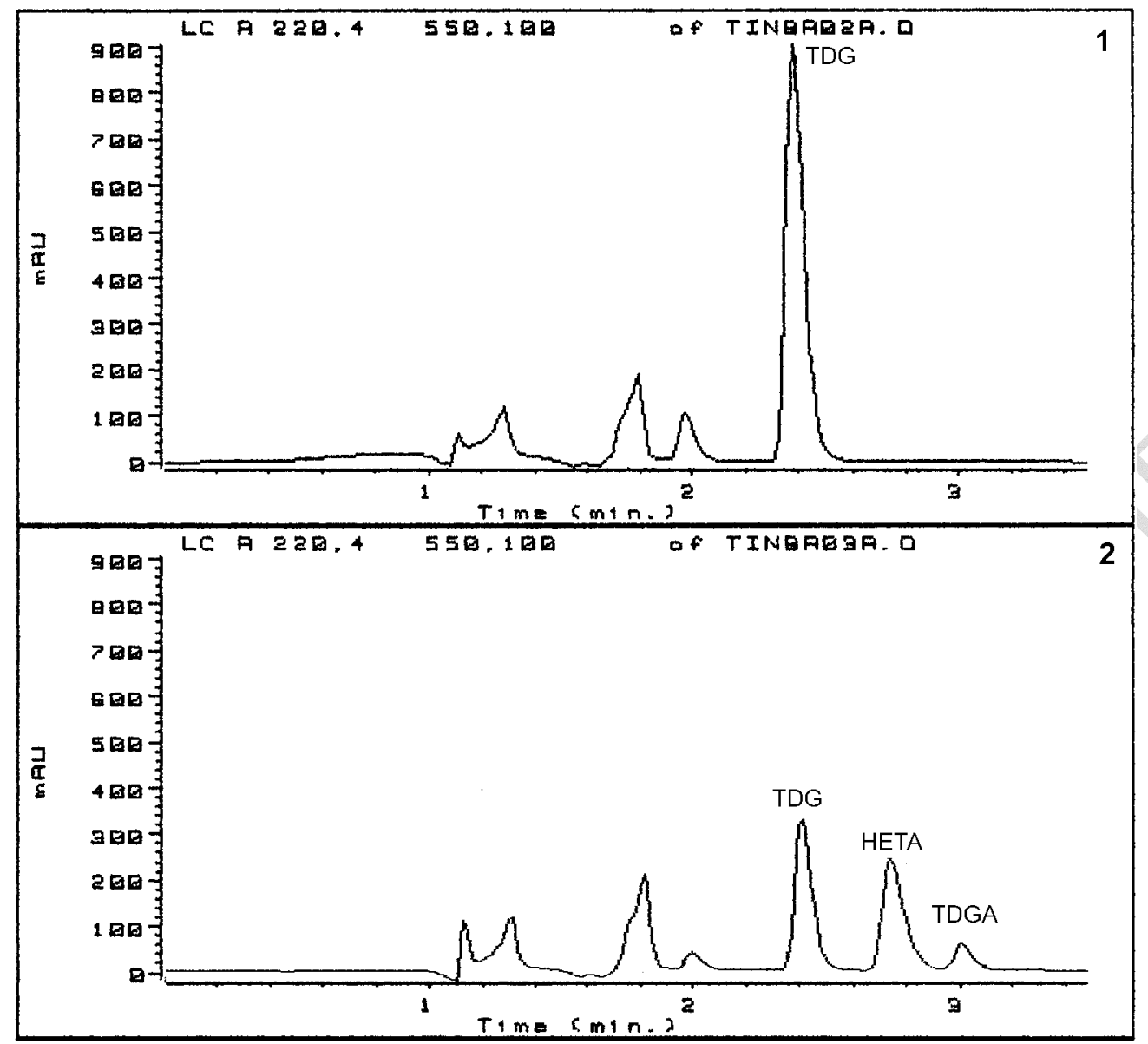


ACCEPTED MANUSCRIPT<smiles>C[As](C)(C)SCC(=O)O</smiles>

Acetic Thioglycolic

Thiodiglycol

acid acid (TGA)

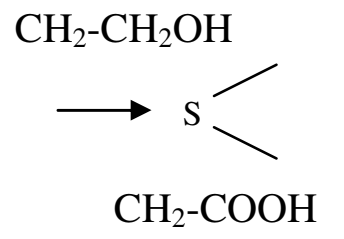

[(2-hydroxyethyl)thio]acetic acid (HETA)

$$
\begin{array}{r}
\mathrm{CH}_{2}-\mathrm{COOH} \\
\longrightarrow \mathrm{CH}_{3} \mathrm{COOH}+\mathrm{HS}- \\
\mathrm{CH}_{2}-\mathrm{COOH}
\end{array}
$$

Thiodiglycolic acid (TDGA)

Achromobacter sp. 75-1

Pseudomonas sp. 93-2

$\mathrm{HS}-\mathrm{CH}_{2-} \mathrm{CH}_{2} \mathrm{OH}$
$\mathrm{CH}_{3} \mathrm{COOH}+\mathrm{SO}_{4}{ }^{2-}$

$\beta$ mercaptoethanol ethanol

Acetic acid

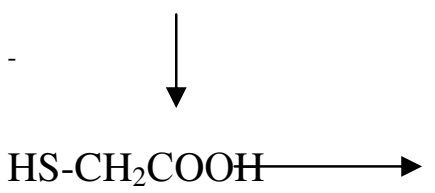

Thioglycolic acid (TGA)

$$
\mathrm{CH}_{3} \mathrm{COOH}+\mathrm{SO}_{4}{ }^{2-}
$$

Acetic acid

*not determined. 
Table 1

Quantities of the chemical munitions and chemical war gases dumped in the southern and western Baltic Sea and Skagerrak (west of Sweden)

\begin{tabular}{|l|l|l|l|}
\hline \multirow{2}{*}{ Area } & \multicolumn{2}{|c|}{ Quantities of } & \multirow{2}{*}{ Types of war gases } \\
\cline { 2 - 3 } & \multicolumn{1}{|c|}{ chemical munitions } & chemical war gases & \\
\hline $\begin{array}{l}\text { Bornholm } \\
\text { Basin } \\
\begin{array}{l}\text { E of } \\
\text { Bornholm) }\end{array}\end{array}$ & $\begin{array}{l}\text { from 35,300 tons } \\
\text { (reliable data) } \\
\text { to 43,300 tons } \\
\text { (unreliable data) }\end{array}$ & $\begin{array}{l}\text { from 5,300 tons } \\
\text { to 6,500 tons }\end{array}$ & $\begin{array}{l}\text { Mustard gas, viscous mustard } \\
\text { gas, Clark I, II, adamsite, } \\
\text { chloroacetophenone (possibly, } \\
\text { phosgene, nitrogen mustard) }\end{array}$ \\
\hline $\begin{array}{l}\text { Area SW of } \\
\text { Bornholm }\end{array}$ & $\begin{array}{l}\text { up to15,000 tons } \\
\text { (unreliable data) }\end{array}$ & 2250 tons & no data \\
\hline Gotland Basin & 2,000 tons & 300 tons & no data \\
\hline Little Belt & 5,000 tons & 750 tons & tabun, phosgene \\
\hline $\begin{array}{l}\text { Skagerrak (W } \\
\text { of Sweden ) }\end{array}$ & $\begin{array}{l}\text { app. 20,000 tons } \\
\text { (quantity not verified) }\end{array}$ & - & $\begin{array}{l}\text { mustard gas } \\
\text { (other types not verified) }\end{array}$ \\
\hline
\end{tabular}


Table 2

Microbiological characteristics of the Baltic Sea near-bottom water

\begin{tabular}{|l|c|c|c|c|}
\hline \multirow{2}{*}{ Dumping site } & Total bacterial & Bacterial & \multicolumn{2}{|c|}{ Number of heterotrophs } \\
\cline { 4 - 5 } & number, & biomass, & Total, & MGHP-degrading microorganisms, \\
& $10^{6} / \mathrm{ml}$ & $\mathrm{mg} / \mathrm{ml}$ & $10^{4} / \mathrm{ml}$ & of total number of heterotrophs \\
\hline Gotland Basin & $1.3-4.2$ & $1.1-3.0$ & $0.6-2.0$ & up to 20 \\
\hline Bornholm Basin & $0.7-5.3$ & $0.6-4.9$ & $0.5-3.2$ & up to 85 \\
\hline Skagerrak Strait & $0.5-7.1$ & $0.4-6.5$ & $0.2-4.9$ & up to 98 \\
\hline
\end{tabular}


Table 3

Taxonomic structure of the bacterioplankton in Southern Baltic Sea

\begin{tabular}{|l|l|}
\hline Out of the dump site & Bornholm dump site \\
\hline Bacillus & Pseudomonas \\
\hline Pseudomonas & Bacillus \\
\hline Alcaligenes & Achromobacter \\
\hline Sphingomonas & Arthrobacter \\
\hline Achromobacter & Others: $<15 \%$ \\
\hline Flavobacterium & \\
\hline Arthrobacter & \\
\hline Acinetobacter & \\
\hline Micrococcus & \\
\hline Flectobacillus & \\
\hline Planococcus & \\
\hline Others: $<25 \%$ & \\
\hline
\end{tabular}


Table 4

Comparative cultivation of the degrader microorganisms on the MGHPs containing medium (60 mg OCS/1 and 0.18\% TDG, $20^{\circ} \mathrm{C}$ )

\begin{tabular}{|c|c|c|c|c|}
\hline \multirow{2}{*}{\begin{tabular}{c} 
Microorganisms \\
\cline { 2 - 5 }
\end{tabular}} & \multicolumn{2}{|c|}{ Static conditions } & \multicolumn{2}{c|}{ Aeration $(15 \mathrm{mM} \mathrm{O} / \mathrm{l} / \mathrm{h})$} \\
\cline { 2 - 5 } & $\begin{array}{c}\text { Biomass gain } \\
\text { (mean } \pm \mathrm{SD}), \%\end{array}$ & $\begin{array}{c}\mathrm{q}_{\max }{ }^{*}(\mathrm{mean} \pm \\
\mathrm{SD}), \mathrm{mg} / \mathrm{g} / \mathrm{d}\end{array}$ & $\begin{array}{c}\text { Biomass gain } \\
(\text { mean } \pm \mathrm{SD}), \%\end{array}$ & $\begin{array}{c}\mathrm{q}_{\max }{ }^{*}(\mathrm{mean} \pm \\
\mathrm{SD}), \mathrm{mg} / \mathrm{g} / \mathrm{d}\end{array}$ \\
\hline Pseudomonas sp. 93-2 & $10.4 \pm 0.6$ & $9 \pm 1$ & $212.1 \pm 6.4$ & $17 \pm 2$ \\
\hline Arthrobacter sp. 23-3 & $17.1 \pm 0.8$ & $19 \pm 2$ & $226.0 \pm 9.4$ & $26 \pm 3$ \\
\hline Achromobacter sp. $75-1$ & $24.0 \pm 1.3$ & $26 \pm 3$ & $267.5 \pm 12.2$ & $37 \pm 4$ \\
\hline
\end{tabular}

$* \mathrm{q}_{\max }$ - maximum specific dechlorination rate, $\mathrm{mg}$ OCS/g biomass/day.

Data are means \pm SD of three independent measurements. 
Table 5

Effect of temperature on growth of degrader-microorganisms under static conditions

\begin{tabular}{|c|c|c|c|}
\hline Microorganisms & $\begin{array}{c}\text { Temperature, } \\
{ }^{\circ} \mathrm{C}\end{array}$ & $\begin{array}{c}\mathrm{Y}^{\mathrm{a}}(\text { mean } \pm \mathrm{SD}), \\
\mathrm{g} / \mathrm{g}\end{array}$ & $\begin{array}{c}\mu_{\max }{ }^{\mathrm{b}}(\mathrm{mean} \pm \mathrm{SD}) \\
\mathrm{g} / \mathrm{g} / \mathrm{d}\end{array}$ \\
\hline \multirow{3}{*}{ Achromobacter sp. 75-1 } & 5 & $0.37 \pm 0.02$ & $0.07 \pm 0.01$ \\
\cline { 2 - 4 } & 20 & $0.39 \pm 0.03$ & $0.23 \pm 0.02$ \\
\cline { 2 - 4 } & 25 & $0.39 \pm 0.04$ & $0.20 \pm 0.01$ \\
\hline \multirow{3}{*}{ Arthrobacter sp. 23-3 } & 5 & $0.23 \pm 0.02$ & $0.07 \pm 0.01$ \\
\cline { 2 - 4 } & 20 & $0.29 \pm 0.02$ & $0.34 \pm 0.03$ \\
\hline \multirow{3}{*}{ Pseudomonas sp. 93-2 } & 25 & $0.31 \pm 0.03$ & $0.30 \pm 0.02$ \\
\cline { 2 - 4 } & 5 & $0.32 \pm 0.03$ & $0.09 \pm 0.01$ \\
\cline { 2 - 4 } & 20 & $0.33 \pm 0.02$ & $0.31 \pm 0.02$ \\
\hline
\end{tabular}

${ }^{\mathrm{a}} \mathrm{Y}$ - biomass yield, $\mathrm{g}$ biomass produced [dry wt]/g substrate utilized.

${ }^{\mathrm{b}} \mu_{\max }$ - maximum specific growth rate, $\mathrm{g} / \mathrm{g}$ biomass/day.

Data are means \pm SD of three independent measurements. 